\title{
Beyond Symbolic Responses to Private Politics: Examining Labor Standards Improvement in Global Supply Chains
}

\section{Citation}

Hugill, Andrea R., Jodi L. Short, and Michael W. Toffel. "Beyond Symbolic Responses to Private Politics: Examining Labor Standards Improvement in Global Supply Chains." Harvard Business School Working Paper, No. 17-001, July 2016.

\section{Permanent link}

http://nrs.harvard.edu/urn-3:HUL.InstRepos:27877656

\section{Terms of Use}

This article was downloaded from Harvard University's DASH repository, and is made available under the terms and conditions applicable to Open Access Policy Articles, as set forth at http:// nrs.harvard.edu/urn-3:HUL.InstRepos:dash.current.terms-of-use\#OAP

\section{Share Your Story}

The Harvard community has made this article openly available. Please share how this access benefits you. Submit a story.

Accessibility 


$$
\text { HAR VAR D B US INESS SCHOOL }
$$

\section{Beyond Symbolic Responses to Private Politics: Examining Labor Standards Improvement in Global Supply Chains}

Andrea R. Hugill Jodi L. Short Michael W. Toffel

Working Paper 17-001 


\title{
Beyond Symbolic Responses to Private Politics: Examining Labor Standards Improvement in Global Supply Chains
}

\author{
Andrea R. Hugill \\ Georgetown University McDonough School of \\ Business \\ Jodi L. Short \\ UC Hastings College of the Law \\ Michael W. Toffel \\ Harvard Business School
}

Working Paper 17-001 


\title{
Beyond Symbolic Responses to Private Politics: Examining Labor Standards Improvement in Global Supply Chains
}

\author{
Andrea R. Hugill \\ Georgetown University McDonough School of Business \\ Jodi L. Short \\ UC Hastings College of the Law \\ Michael W. Toffel \\ Harvard Business School
}

\begin{abstract}
July 1,2016
Worker rights advocates seeking to improve labor conditions in global supply chains have engaged in private political strategies prompting transnational corporations (TNCs) to adopt codes of conduct and monitor their suppliers for compliance, but it is not clear whether organizational structures established by TNCs to protect their reputations can actually raise labor standards. We extend the literature on private politics and organizational self-regulation by identifying several conditions under which codes and monitoring are more likely to be associated with improvements in supply chain working conditions. We find that suppliers are more likely to improve when they face external compliance pressure in their domestic institutional environment, when their buyers take a cooperative approach to monitoring, and when their auditors are highly trained. We find, further, that a cooperative approach to monitoring enhances the impact of auditor training, and that auditor training has a greater impact on improvement when coupled with a cooperative approach than with external compliance pressures. These findings suggest key considerations that should inform the design and implementation of monitoring strategies aimed at improving conditions in global supply chains as well as theory and empirical research on the organizational outcomes of private political activism for social change.
\end{abstract}

Since the 1990s, the struggle to improve working conditions in global supply chains has been fought largely in the realm of private politics. As macro-economic, political, and social conditions associated with globalization have eroded the actual and perceived power of states to regulate labor standards and market conditions, workers' rights advocates who previously mobilized to change state policy have increasingly shifted their activism directly against transnational corporations (TNCs) (Bartley and Child, 2014; Mena and Waeger, 2014). "The 
anti-sweatshop movement arguably made the TNC into the central locus of struggle over labor rights and globalization at the turn of the twenty-first century" (Bartley and Child, 2014: 657). Interest groups and their private politics strategies have had far-reaching effects in shaping the way TNCs structure the governance of their global value chains. To avoid the negative publicity generated by anti-sweatshop activism, thousands of TNCs, including all US Fortune 500 companies, have adopted codes of conduct that require suppliers to meet specified workplace standards (McBarnet, 2007). Many of these companies also conduct "social audits" to monitor their global value chains and assess suppliers' adherence to those codes (Short, Toffel, and Hugill, 2016). Codes and auditing are also used by the scores of multi-stakeholder initiatives that provide collective fora for private regulation of supply chain practices. Organizations like the Roundtable on Sustainable Palm Oil, the Electronics Industry Citizenship Coalition, and the Ethical Trading Initiative bring together representatives from industry and civil society to set standards for supply chain practices and certify members' compliance through social auditing. Hundreds of thousands of audits are conducted on behalf of individual firms and multi-stakeholder initiatives each year (Gould, 2005), making social auditing an $\$ 80$ billion industry (AFL-CIO, 2013).

While TNCs initially adopted codes and monitoring for business purposes, including information gathering and reputation management, these organizational structures are increasingly being embraced by nongovernmental organizations (NGOs), governments, intergovernmental organizations, and businesses as a mechanism for achieving the social goal of improving conditions for workers in global supply chains (Utting, 2005; LeBaron and Lister, 2015). Codes and monitoring are now central to the strategy of NGOs that alternately agitate and partner with TNCs to encourage ever-stricter standards and more robust private monitoring 
to improve labor conditions (Bartley, 2007; King and Pearce, 2010; LeBaron and Lister, 2015). Codes and monitoring are the bases of recently enacted regulatory regimes in many countries that seek to improve supply chain practices by requiring TNCs to conduct supply chain due diligence and publicly disclose their findings (Nolan, 2014). Codes and monitoring are the lynchpin of prominent United Nations initiatives in the area of business and human rights, like the Global Compact and the Guiding Principles on Business and Human Rights, which rely on the voluntary implementation of private standards and monitoring to improve global labor conditions (Ruggie, 2008). Responding to this pervasive demand for improvement, leading social auditing firms advertise that their services will help "both suppliers and customers in implementing sustainable business practices and improving workplace conditions in global supply chains" (UL Responsible Sourcing, 2015; see also Elevate, 2016; Intertek, 2016). Despite all this, many have argued that codes and monitoring ostensibly meant to improve working conditions in global supply chains are, at best, window-dressing (Esbenshade, 2004; Frynas, 2005; Seidman, 2007; Barkemeyer, 2009) or, worse, a calculated ploy to undermine labor organizing efforts (Justice, 2006) and fend off more stringent state regulation (Utting, 2005; Barkemeyer, 2009; Shamir, 2011).

This debate presents a classic institutional puzzle: can organizational structures established for business purposes achieve normative goals like raising labor standards? In this paper, we extend the literature on private politics and organizational self-regulation by identifying some of the conditions under which supply chain codes and monitoring are more likely to be associated with improvement in working conditions. Using a novel dataset drawn from thousands of audits for code-of-conduct compliance in 66 countries by one of the world's largest supply chain auditing firms, we investigate how compliance improvement rates differ 
among suppliers depending on both institutional compliance pressure and social auditing program design. We also, for the first time, test the interaction of institutional pressures and design features.

We find that suppliers are more likely to improve when they face compliance pressure in their domestic institutional environment, when their buyers take a cooperative approach to monitoring, and when their auditors are highly trained. We find, further, that a cooperative approach to monitoring enhances the impact of auditor training, while having more highly trained auditors yields no measurable influence on the improvement rates of suppliers facing external compliance pressures in their institutional environment. These findings suggest key considerations that should inform both the design and implementation of monitoring strategies aimed at improving conditions in global supply chains as well as theory and empirical research on the organizational outcomes of private political activism for social change.

\section{PRIVATE POLITICAL ACTIVISM AND ORGANIZATIONAL SELF-REGULATION}

Two streams of research inform our investigation of the conditions under which private codes and monitoring can be effective: the literature on private politics and the literature on organizational self-regulation. Private politics research has focused on the way actors mobilize for and respond to collective action in markets in order to contest either the behavior of market actors or the harmful conditions produced by markets (Baron, 2003; King and Pearce, 2010). Research on self-regulation, by contrast, has examined whether and how certain structures and logics embedded in organizations can change organizational practices (e.g., Ayres and Braithwaite, 1992; Edelman, 1992; Selznick, 1992; Dobbin and Sutton, 1998; Parker, 2002). The fundamental theoretical concern of both literatures is how collective action can change the 
behavior of organizations in markets without reliance on the coercive power of law or the state (Baron, 2003; King and Pearce, 2010; Short and Toffel, 2010).

Private politics research has produced significant insights about private political strategy, both from the perspectives of the activists and their corporate targets. This literature has revealed how activists select targets (Baron and Diermeier, 2007; Bartley and Child, 2014; Mena and Waeger, 2014; McDonnell, King, and Soule, 2015), the negative economic impact activist campaigns can have on corporate targets (King and Soule, 2007), the conditions under which companies tend to respond to activist campaigns (Eesley and Lenox, 2006; King, 2008), and the measures corporate organizations have tended to adopt in response to activism (King, 2008; Soule, 2009; McDonnell and King, 2013). While studies have examined the outcomes produced by private political campaigns, they have focused on the institutional logics and organizational forms companies have adopted in response to activism (King and Pearce, 2010) rather than on whether these structures actually change company practices. For instance, we know that companies often respond to private political activism by publicly committing to uphold the values advocated by the activists (Eesley and Lenox, 2006; King, 2008; Soule, 2009; McDonnell and King, 2013) and that some companies go further to demonstrate their commitment by creating formal organizational structures, like corporate social responsibility (CSR) board committees, or by engaging in practices like CSR reporting (McDonnell, King, and Soule, 2015). However, these studies reveal little about whether such organizational structures significantly change the behavior of the companies that adopt them or whether they are merely symbolic gestures (De Bakker et al., 2013).

Certainly, TNCs' supplier codes of conduct and monitoring regimes bear all the hallmarks of "myth and ceremony" (Meyer and Rowan, 1977). It would be difficult to find 
organizational structures that more "dramatically reflect the myths of their institutional environments instead of the demands of their [organizations'] work activities" (Meyer and Rowan, 1977). Corporate organizations adopted codes and monitoring largely in response to coercive and mimetic external pressures (Suchman, 1995). Initially, companies adopted these self-regulatory regimes for instrumentally rational business purposes: to deflect or avoid negative publicity generated by anti-sweatshop campaigns in order to preserve corporate assets like brand value and reputation (Bartley and Child, 2014; Mena and Waeger, 2014). Codes and monitoring diffused rapidly throughout the field of TNCs as companies imitated the aggressively marketed embrace of these structures by industry leaders like Nike and Apple and as stakeholders like NGOs and shareholder activists made them into touchstones of transnational corporate legitimacy (Etzion and Ferraro, 2010). However, the substantive changes in production practices that such structures formally require of supply chain factories—-for instance, minimum wage requirements, overtime restrictions, and freedom of association rights for workers - are fundamentally at odds with the economic logic of the extended global value chain (Locke, 2013). Thus, they are ripe for decoupling (Meyer and Rowan, 1977; Meyer et al., 1997). Literature on organizational self-regulation suggests that, despite strong pressures to decouple self-regulatory structures from actual practices, companies do sometimes effectively implement self-regulation. However, theory (Campbell, 2007) and empirical studies have found that meaningful self-regulation tends to depend on robust government monitoring (Short and Toffel, 2010; Lim and Tsutsui, 2012; Short, 2013; Marquis and Qian, 2014). Other research that has identified successful implementation of organizational self-regulation has studied voluntary programs that are implemented in the context of a broader, legally backed state regulatory regime such as American anti-discrimination law (Kalev, Dobbin, and Kelly, 2006) or 
environmental law (Potoski and Prakash, 2005). Similarly, studies specifically investigating suppliers' compliance with labor codes of conduct have found that codes and monitoring tend to be associated with better working conditions when combined with governmental regulatory efforts (e.g., Rodriguez-Garavito, 2005; Seidman, 2007; Amengual, 2010; Locke, Rissing, and Pal, 2013; Toffel, Short, and Ouellet, 2015).

The literature on self-regulation has yet to address the question of whether private organizational governance structures that were adopted in response to private political activism can alter market behavior outside the shadow of a robust state-based regulatory regime. This is a significant gap, because global value chains extend into many countries where governmental monitoring and enforcement is weak or lacking (Frynas, 2005). "Today, garment and electronic factories from Vietnam to Honduras are often more likely to be inspected by private social auditing firms than government workplace inspectors" (Anner, 2012: 610).

Although there are many studies on supplier codes of conduct, none address this precise question. Most research in this field has measured levels of supplier compliance at a particular moment in time rather than compliance improvement over time (e.g., Egels-Zandén, 2007; Locke, Qin, and Brause, 2007; Oka, 2010a, 2010b; Ang et al., 2012; Bartley and Egels-Zandén, 2015; Toffel, Short, and Ouellet, 2015). Thus, these studies cannot address questions about the conditions producing change in markets.

A few studies have observed that, in the aggregate, supplier compliance with codes has improved over time (Locke, Qin, and Brause, 2007; Shea, Nakayama, and Heymann, 2010; Nadvi et al., 2011; Ang et al., 2012; Locke, Rissing, and Pal, 2013; Toffel, Short, and Ouellet, 2015). Others have shown that labor code compliance tends to improve more rapidly in some code categories, like health and safety, than in others, like freedom of association (Barrientos and 
Smith, 2007; Ruwanpura, 2012). However, these studies have not hypothesized what conditions are associated with improvement.

The few studies that have empirically examined factors associated with code compliance improvement have significant limitations. For instance, Weil and Mallo (2007) and Ang et al. (2012) investigated factors associated with improvements in labor standards compliance, but both studies measured these factors, as well as the compliance improvement rates themselves, using data aggregated by market (that is, at the national or regional level), leaving open the question of what accounts for individual suppliers' improvement (or failure to improve). Similarly, while Locke, Rissing, and Pal (2013) discuss factors associated with improvement in labor conditions at a few individual factories, their findings fail to identify factors that can explain why some improve and others do not, because each of the factories in their matchedpairs case study improved. To our knowledge, no study has investigated the factors associated with different suppliers' differing rates of improvement.

Our study seeks to fill this gap by investigating the factors that predict which suppliers are more likely to improve their compliance with codes of conduct. We argue that such improvement, particularly in a domain where it is not obviously motivated by the shadow of legal consequences, will be driven not only by the kind of institutional compliance pressures long theorized in the self-regulation literature, but also — and crucially—by the transfer of compliance knowledge between auditors and the suppliers they audit. Drawing on both the literature on private standards compliance and the broader literature on how knowledge is transferred across organizations, we argue that suppliers subject to codes and monitoring are most likely to improve when they are subject to monitoring regimes designed to promote the transfer of compliance knowledge from auditors to suppliers. 


\section{Institutional Compliance Pressures}

Like most public regulatory regimes, many private regulatory regimes rely on the principles of deterrence theory to shape behavior. Briefly stated, they attempt to incentivize desired behavior by lowering its costs or to curb unwanted behavior by increasing its costs (Locke, Amengual, and Mangla, 2009). Unwanted behavior is deterred through various types of penalties, ranging from fines to reputational damage to adverse business consequences, but penalties can only be imposed if the unwanted behavior is detected. Thus, the prospect of detection raises the probability of punishment and creates pressure on regulated entities to comply - the greater the probability of detection, the greater the pressure.

Although government inspection regimes are often weak in the countries where global suppliers are located, research suggests that civil society actors like NGOs and the press can serve as key sources of compliance monitoring and pressure (Seidman, 2007; Mattli and Woods, 2009; Fransen, 2012). The local press and local NGOs play key roles in transnational advocacy networks that promote global norms such as labor standards and human rights (Keck and Sikkink, 1998: 3). The high-profile, international NGOs that are often at the center of transnational advocacy networks depend heavily on local NGOs to collect information about violations of global norms by local actors. For instance, the strategy of the global anti-sweatshop movement has been to work with local NGO partners to identify which local firms supply targeted global brands and to do the painstaking investigative work required to reveal exploitive labor practices at these suppliers (Bartley and Child, 2014). Local NGOs, in turn, depend on domestic media and domestic channels of communication to transmit information about exploitive practices to their more powerful international counterparts in the advocacy network (Keck and Sikkink, 1998; Bartley and Child, 2014). The more free and open these information 
channels, the more likely local abuses are to attract local and international attention, condemnation, and discipline (King, 2014).

To date, research on civil society pressure and standards compliance has focused on how monitoring by civil society actors affects compliance levels at a particular point in time. Toffel, Short, and Ouellet (2015), for instance, have demonstrated that suppliers in countries with more press freedom exhibit higher compliance with codes of conduct, suggesting a role for the press in enforcing supply chain standards. Lim and Tsutsui (2012) demonstrate that NGO pressure influences the likelihood that TNCs will commit to the principles contained in the United Nations Global Compact, and Seidman (2007) suggests the key role of NGOs in enforcing the private Rugmark certification regime regulating the use of child labor in carpet manufacturing.

We argue here that institutional pressure generated by civil society actors like the press and NGOs can likewise motivate suppliers to improve compliance. When suppliers' failure to meet the global norms of behavior prescribed by codes of conduct is documented in social audits, those suppliers become attractive targets for transnational advocacy networks seeking to raise international labor and human rights standards. ${ }^{1}$ The modus operandi of these networks is to identify violators of global norms and induce them to change (Keck and Sikkink, 1998: 3). Local NGOs in these networks see their role as "promoting change by reporting facts" that can attract the attention and support of international NGOs, press, and policymakers (Keck and

\footnotetext{
${ }^{1}$ In a context very different from ours, studies have suggested that activists and the press are more likely to target companies with strong reputations for social responsibility performance (Luo, Meier, and Oberholzer-Gee, 2012; Bartley and Child, 2014) or companies that have adopted extensive organizational structures to implement their CSR initiatives (McDonnell, King, and Soule, 2015) than they are to go after the worst-behaved companies. We do not dispute these findings, but we note that these studies focus on very different contexts and actors than those we study here. Those studies focused on activism directed toward branded multinational companies with reputations to protect because activists can exercise more leverage over such firms: the better a brand's reputation, the more significant the financial consequences of reputational damage. Such is not the case with the subjects of our study: local suppliers in developing countries. They are unbranded, largely invisible to consumers, and thus more insulated from this kind of reputational threat. As suggested in the literature on transnational advocacy networks, we believe that activists will select their targets very differently in these local settings and will attempt to identify the worst practices by local suppliers in order to gain the most leverage over the global brands that are the activists' ultimate targets.
} 
Sikkink, 1998: 19). A free local press helps them discover and publicize facts about labor abuses at suppliers, increasing the prospect that such suppliers will be disciplined by their buyers or will suffer political, legal, or economic consequences in their home markets (Fransen, 2012; Berliner et al., 2015). Consequently, we expect that suppliers in countries with high institutional pressure from civil society actors like the local press and NGOs will be especially motivated to improve in order to avoid scrutiny, negative publicity, and penalties.

Hypothesis 1 (H1): Suppliers will improve more when located in institutional environments in which noncompliance with codes of conduct is more likely to be exposed and sanctioned.

\section{Cooperative Approach to Social Auditing}

Some commentators have questioned the efficacy of punitive approaches to enforcing codes through monitoring and have advocated a more cooperative or "commitment-oriented" approach to supplier monitoring programs (Locke, Amengual, and Mangla, 2009). Rather than using supplier audits to detect compliance violations and threaten sanctions, the cooperative approach sees audits as an opportunity "to engage in a process of root-cause analysis, joint problem solving, information sharing, and the diffusion of best practices that is in the mutual self-interest of the supplier, the auditors, and the global corporations for which they work" (Locke, Amengual, and Mangla, 2009: 321). The theory underlying such an approach, developed most extensively by Ayres and Braithwaite in Responsive Regulation (1992), is that cooperation on the part of regulators will induce regulated entities to reciprocate with compliance.

Studies have suggested that a cooperative approach to social auditing can help buyers, suppliers, and auditors develop trusting and cooperative relationships that are more likely to motivate improved compliance than more punitive, arms-length approaches will do (Frenkel and 
Scott, 2002; Locke and Romis, 2007). Locke and Romis (2007), for instance, find better compliance with labor standards at a Nike supplier that had regular, face-to-face contact with Nike's compliance staff than a supplier that had a more distant, formal relationship with Nike's monitors. They argue that these ongoing interactions led to "transparency and trust ... as well as joint problem solving" (Locke and Romis, 2007: 60) between Nike and the compliant plant. By contrast, the plant that had less direct interaction with Nike's monitors viewed the company's standards as little more than hurdles it had to clear to continue receiving orders. Similarly, in studies of compliance with government regulation, research has shown that the coercive threat of penalties can undermine a firm's motivation to cooperate with regulators (Bardach and Kagan, 1982; Ayres and Braithwaite, 1992; Short and Toffel, 2010).

In the supply chain audit context, one way that buyers can signal their intention to cooperate with a supplier is to notify the supplier in advance that an audit will be occurring. This signals the buyer's willingness to trust the supplier by making the buyer vulnerable to the possibility of opportunism on the part of suppliers who might use the time afforded by advance notice to hide their misdeeds (Mayer, Davis, and Schoorman, 1995). In fact, it is this very vulnerability that makes announcing audits a controversial approach. On the one hand, some have argued that it simply gives suppliers time to cover up their bad behavior (AFL-CIO, 2013; Clean Clothes Campaign, 2005; LeBaron and Lister, 2015) and there is some empirical evidence that this may be the case (Gray, 2006; Marks, 2012; Toffel, Short, and Ouellet, 2015). Worker rights advocates have therefore long favored unannounced audits (Frenkel and Scott, 2002). On the other hand, unannounced audits meant "to catch managers unaware" and impede their ability to hide violations "may, for now, help buyers to learn more about the real conditions in factories," but this "aggravates the relationship between buyers and suppliers ... [and] make[s] it 
difficult to achieve any sustainable change" (Gould, 2005: 28).

Our interviews with brands' ethical supply chain managers and social auditors from several firms consistently indicated that unannounced audits convey distrust and a policing relationship, with auditors sometimes denied entry to factories, whereas announced audits convey a more trusting and cooperative relationship. Thus, although an announced audit might uncover fewer violations than an unannounced audit, we argue that it can pay dividends down the road by encouraging suppliers to reciprocate with increasing compliance.

Hypothesis 2 (H2): Suppliers in cooperative monitoring relationships will improve more than other suppliers.

\section{Auditor Training}

There is much skepticism about whether social auditing can foster improvement, given questions that have been raised about the competence of the auditors and the integrity of the social auditing process (O’Rourke, 2002; Esbenshade, 2004; LeBaron and Lister, 2015). Critics charge that auditors lack the requisite knowledge and independence to detect labor abuses (O’Rourke, 2002; Esbenshade, 2004; Locke, Amengual, and Mangla, 2009; AFL-CIO, 2013), that they "shade their findings depending on the client" (LeBaron and Lister, 2015), that they are easily duped by managers who cook the books and coach employees to lie about workplace conditions (AFL-CIO, 2013), and that some are outright corrupt, taking bribes and favors from the suppliers they audit (Clean Clothes Campaign, 2005). Others allege that auditors are stuck in an ever more sophisticated "cat and mouse" game with suppliers that duplicitously maintain fake wage and hours records and coach their workers on how to answer auditors' questions (Power, Ng, and Singh, 2008; Karunakaran, 2013; LeBaron and Lister, 2015). Research has documented biases in the way social auditors record supplier code of conduct violations based, for instance, on whether or not the supplier is paying for the audit and on whether or not the auditor has a 
longstanding relationship with the supplier (Short and Toffel, 2015; Short, Toffel, and Hugill, 2016).

Some, including critics of social auditing, have suggested that auditors can be more effective when they are more highly trained (Locke, Amengual, and Mangla, 2009; AFL-CIO, 2013) and there is evidence supporting this. Research on social auditors has found that bettertrained auditors identify more violations than less-trained ones (Short, Toffel, and Hugill, 2016).

We argue here that training will likewise enable auditors to help suppliers improve following an audit. Our interviews with auditors and managers at social auditing firms reveal that the auditors' training typically teaches them what different violations look like, how to find violations, and what conditions tend to cause them. Such training is likely to enable auditors not only to detect violations, but also to identify their root causes and thus to help the suppliers devise solutions. Recent evidence has indicated that government inspections can prompt improved working conditions (Levine, Toffel, and Johnson, 2012), suggesting that inspectors might play a dual role of assessing current conditions while suggesting pathways to improve. Studies in the knowledge transfer and learning literatures support this intuition, finding that certain types of training can improve the trainees' ability to apply and convey information in personal interactions such as negotiations (Thompson, Gentner, and Loewenstein, 2000; Loewenstein, Thompson, and Gentner; 2003; Nadler, Thompson, and Van Boven, 2003) and that information is more likely to be absorbed and acted upon when it comes from a source perceived to have expertise (Borgatti and Cross, 2003; Thomas-Hunt, Ogden, and Neale, 2003; Reinholt, Pederson, and Foss, 2011). We therefore hypothesize:

Hypothesis 3 (H3): Suppliers will improve more following audits conducted by audit teams that are more highly trained. 


\section{Interaction of Auditor Training and Supplier Learning Motivations}

Improving supplier practices through auditing requires not only a knowledgeable auditor, but also a willing supplier to receive the information conveyed. A substantial body of literature suggests that individuals and organizations share and absorb knowledge more effectively in collaborative, cooperative, and trusting relationships (Coleman, 1988; Szulanski, 1996; Dyer and Chu, 2003; McEvily, Perrone, and Zaheer, 2003; Inkpen and Tsang, 2005; Obstfeld, 2005). For instance, Cheng, Yeh, and Tu (2008) show that the transfer of green production practices from buyers to suppliers is most effective when buyers let suppliers participate in decision making and when those buyers and suppliers trust one another. Buyers and suppliers surveyed by Oka (2010b) similarly reported that more learning about compliance with workplace standards occurred in trusting and cooperative relationships. These arguments lead to the following moderated relationship:

Hypothesis 4 (H4): Suppliers audited by highly trained auditors will improve more in cooperative monitoring relationships than in other contexts.

In contrast to the demonstrated synergies between learning and cooperation, studies have found that the threat of punishment can be detrimental to learning (Deci and Ryan, 1985), especially to learning how to improve compliance over time (e.g., Bardach and Kagan, 1982; Ayres and Braithwaite, 1992). Tenbrunsel and Messick (1999: 688) explain that fear of punitive sanctions can blunt improvement because the decision to comply is then "mainly about averting penalties or achieving rewards" rather than about achieving the best performance possible. Firms motivated primarily by the fear of sanctions may learn enough to avoid the sanctions, but will not be motivated to improve any further.

In addition, a punitive approach to enforcement may sour relationships between suppliers and auditors, making it "very hard to initiate any improvements" (Gould, 2005: 28). Researchers 
have suggested that suppliers subjected to a punitive monitoring approach are more likely to try to hide their wrongdoing, thus shifting scarce resources away from the task of actually improving working conditions (Plambeck and Taylor, forthcoming). In a different context, Short and Toffel (2010) have demonstrated that firms threatened with penalties if they failed to adopt an internal compliance program did not successfully implement the program they adopted and did not improve their compliance.

The foregoing arguments suggest that suppliers have two motivations to improve their compliance after an audit. Those facing external compliance pressures in environments with significant press freedom may fear exposure and possible sanctions. Those in cooperative monitoring arrangements may desire to reciprocate the monitor's trust. We argue here that highly trained auditors will foster more compliance learning and consequently greater compliance improvement by suppliers in cooperative monitoring relationships than by suppliers whose primary motivation to improve is fear.

Hypothesis 5 (H5): Auditor training will have a greater influence on supplier improvement in cooperative monitoring relationships than it will when poor compliance is more likely to be exposed and sanctioned.

\section{DATA AND METHOD}

\section{Empirical Context and Sample}

We tested our hypotheses using data from code-of-conduct audits conducted by a large social auditing company (henceforth, the "social auditor") that requested anonymity. The data includes audits conducted from 2004 through 2009, the most recent six-year period for which we could obtain access. Various characteristics of the audits, auditors, and audited suppliers were provided, including unique identifiers (but not names) for the auditors, the suppliers, and the buyers on whose behalf the audits were conducted. While many buyers issue their own supplier 
code of conduct, our discussions with the social auditor revealed that the differences between these codes are slight, which gave us confidence in treating all of these audits similarly.

Because our empirical specification requires data from a supplier's focal (current) audit and its prior audit, our sample is limited to those suppliers for which our data includes at least two audits. Our estimation sample consists of 8,677 focal audits conducted at 4,940 suppliers spanning 13 industries in 66 countries. The most common industries in our sample are garments, accessories, electronics, and toys (see Table 1). The majority of the audits took place in China; many of the rest took place elsewhere in Asia (India, Bangladesh, India, Indonesia, the Philippines, and Vietnam) and in North America (Mexico and United States) (see Table 2).

[Insert Tables 1 and 2 here]

\section{Dependent Variable}

Our dependent variable measures a supplier's improvement between its prior and focal audits, which we calculate by dividing the number of violations from the focal audit plus 1 by the number of violations from the previous audit plus 1 , then taking the natural log of that ratio:

$$
\mathrm{y}_{\mathrm{i}, \mathrm{t}}=\ln \left[\left(\mathrm{V}_{\mathrm{i}, \mathrm{t}}+1\right) /\left(\mathrm{V}_{\mathrm{i}, \mathrm{t}-1}+1\right)\right],
$$

where $\mathrm{V}_{\mathrm{i}, \mathrm{t}}$ is the number of violations for supplier $\mathrm{i}$ audited at time $\mathrm{t}$ that pertain to child labor, forced or compulsory labor, working hours, occupational health and safety, minimum wage, treatment of foreign workers and subcontractors, and disciplinary practices, and $\mathrm{V}_{\mathrm{i}, \mathrm{t}-1}$ is the comparable figure from the prior audit at time $t-1 .^{2}$ We add 1 - the lowest value of the violation count after zero - to both the numerator and the denominator to avoid losing observations in

\footnotetext{
${ }^{2}$ We excluded violations that, according to our data provider, do not apply to all suppliers (dormitory conditions, and canteen violations) or were interpreted differently by auditors in different countries (freedom of association, the right to organize and bargain collectively, legal or client requirements).
} 
which either the current or prior audit yielded zero violations. ${ }^{3}$ This metric, rather than the simple difference in violations, facilitates proportional comparisons between suppliers. ${ }^{4}$

Moreover, it provides a more reliable estimate than a percent change metric, which can be overly sensitive to outliers and can inflate big changes. ${ }^{5}$ Finally, our log form enables a straightforward interpretation of our coefficients as elasticities.

\section{Independent Variables}

The extent to which a supplier's labor abuses documented in social audits risk being exposed and sanctioned depends on press freedom and NGO presence. We measure press freedom using the Press Freedom Index from Reporters without Borders, which reflects the extent to which journalists faced direct and indirect threats such as imprisonment, physical attacks, and censorship. We reverse-code the raw Press Freedom Index values so that higher values indicate greater press freedom, rescale the result to range from 0 to 1 , and take the $\log$ (after adding 1) to reduce skew. We measure NGO density as the number of NGOs in the supplier's country per million population in that country, which we also log to reduce skew. We obtained NGO data from the Union of International Associations and population data from the US Census Bureau's International Data Base. Because press freedom and NGO density are highly correlated $(\rho=0.83)$, we use principle components analysis (PCA) as a data reduction technique. The first component's eigenvalue of 1.85 is the only one to exceed the conventional

\footnotetext{
${ }^{3}$ Though only $4 \%$ of the prior audits in our sample had zero violations, such suppliers might be distinctively capable of exemplary performance and allowing these observations to drop out of the sample risks introducing bias. ${ }^{4}$ For example, our metric considers the proportional reduction from 12 to 6 violations at a large supplier to be equivalent to a small supplier's reduction from 4 to 2 violations, whereas a difference metric would consider the former to be three times the magnitude of the latter.

${ }^{5}$ For example, skewness declines by a factor of 10 from a value of 4.2 for percent change to a mere 0.4 for our improvement metric and kurtosis declines by a factor of nearly 7 from 30.5 for percent change to 4.5 for improvement.
} 
threshold of 1 and it explains 92.3 percent of the variance between press freedom and NGO density. We refer to this first component as exposure risk. ${ }^{6}$

Whether an audit was expected or a surprise was measured by announced, a dichotomous variable coded 1 when the supplier had advance notice of the audit date and coded 0 for unannounced audits, based on data from the social auditor. Whether an audit is announced or unannounced is typically determined by the buyer on whose behalf the audit is being conducted. In our sample, 76 percent of the audits were announced.

We calculate auditor training as the sum of audit training courses an auditor had takenwhich may address audit skills, specific audit topics, specific client issues, and certification schemes such as SA 8000 — based on data provided by the social auditor. ${ }^{7}$ Because audits are typically conducted by an audit team, we measure maximum auditor training as the largest number of training courses that any team member had undergone by the time the audit was conducted, which we $\log$ after adding 1 to reduce skew and then standardize to facilitate interpretation. The maximum number of training courses for audit teams averaged 6.9.

\section{Audit-level Control Variables}

We control for numerous audit-level factors by constructing variables from data provided by the social auditor. We control for the violations in the prior audit because suppliers whose prior audit yielded many violations face a different opportunity set than suppliers with a "cleaner" history; this may influence their likelihood of improvement. Violations (prior audit) is the number violations from a prior audit, top-coded at the 99th percentile of the sample

\footnotetext{
${ }^{6} \mathrm{We}$ report robustness tests below that show that our primary results hold when we estimate models that use press freedom and NGO density instead of exposure risk.

${ }^{7}$ Training regarding audit skills helps auditors generally identify violations of codes of conduct. Training regarding specific audit topics includes courses on issues relevant to a specific industry, region, or supplier. Specific audit training could be about an issue such as child labor that could be a common problem for a particular supplier. Training on client issues educates auditors about certain codes of conduct the client is particularly concerned about or a specific protocol the client has agreed to comply with, such as SA8000.
} 
distribution (25 violations) to reduce the potential impact of outliers and taking the log (after adding 1).

Because prior research indicates that auditing is less stringent when suppliers pay their own auditors (Jiang, Stanford, and Xie, 2012; Duflo et al., 2013; Short and Toffel, 2015), we created three dummy variables to indicate who paid for the audit: paid by the supplier or third party, paid by the buyer (on whose behalf the audit was conducted), and paid by unknown entity (to denote instances when we lacked information about who paid).

Re-audits typically have a more limited scope because they tend to focus on concerns raised at the prior audit. Because this could mechanically affect improvement rates, we include three dummy variables as controls: (1) prior audit was re-audit, but focal audit was not; (2) focal audit was re-audit, but prior audit was not; (3) prior and focal audit were re-audits. The baseline condition is that neither the prior nor the focal audit was a re-audit.

Our interviews with social auditors - at the firm that provided us data and at other firms - indicated that the staff hours required to conduct an audit is a reasonable proxy for factory size and complexity, factors that could be associated with improvement but for which direct measures are not available. In addition, more audit staff-hours in a prior audit might enable more opportunity to transfer information between the audit team and the supplier. ${ }^{8}$ We therefore control for auditor exposure (prior audit), which we calculated by taking the log (after adding 1) of the number of staff hours required to conduct the supplier's prior audit, using data from the social auditing firm.

\footnotetext{
${ }^{8}$ We include in our model a dummy variable to denote the nearly $50 \%$ of observations for which the number of staff hours required to conduct the prior audit was missing from the database and where we thus recoded auditor exposure (prior audit) observations from missing values to 0 . This common econometric approach is algebraically equivalent to recoding those missing values with the variable's mean (Greene, 2007: 62).
} 
Audit teams containing individuals who had previously audited the supplier have been shown to report fewer violations than teams whose members have no prior history at that supplier (Short, Toffel, and Hugill, 2016). We therefore created previous auditor as a dummy coded 1 when at least one member of the audit team had participated in the prior audit of that supplier and coded 0 otherwise. Because suppliers may remediate compliance problems identified at prior audits and face increasing mitigation costs, we control for audit sequence by including a series of dummies denoting the supplier's first audit in the sample, the second, and so on.

Because an audit team's gender composition has been shown to affect audit results (Short, Toffel, and Hugill, 2016), we include three dummy variables: all-female audit team, mixed-gender audit team, and all-male audit team. ${ }^{9}$

We control for team experience, which has been shown to affect reported violations (Short, Toffel, and Hugill, 2016). We measure the maximum auditor tenure of each team as the maximum years of service with the social auditor among all team members. We include in our model both maximum auditor tenure and its squared value because the influence of experience on reported violations has been found to be nonlinear (Short, Toffel, and Hugill, 2016).

\section{Institutional Control Variables}

Several factors pertaining to the supplier's institutional environment have been shown to affect violation rates (Toffel, Short, and Ouellet, 2015) and could affect improvement rates, and

\footnotetext{
${ }^{9} 50 \%$ of our sample had all-female audit teams, $32 \%$ had all-male audit teams, and $15 \%$ had teams evenly split between male and female auditors. The remaining $3 \%$ had teams that were $25 \%, 33 \%, 66 \%$, or $75 \%$ female. Therefore, while we observe precise proportions of each team's gender composition, our dummies better reflect the distribution of our data than would a continuous percentage metric.
} 
so we control for them at the time of the prior audit. ${ }^{10}$ A supplier country's dependence on foreign direct investment (FDI) might influence the extent to which the supplier perceives the need to respond to international pressure to improve how its factories are managed. Thus, we control for each supplier country's percentage of gross domestic product (GDP) that is made up of foreign direct investment (FDI inflows) in the year of the prior audit, based on World Bank data. $^{11}$

Because legal protection for collective labor rights could influence how much pressure to improve suppliers perceive they are under, we obtain labor laws scores from Mosley (2011). These scores measure the extent to which domestic law provides collective labor rights such as the rights to join unions and strike, whether government approval is required for collective bargaining, and whether laws restrict worker rights in export processing zones (Greenhill, Mosley, and Prakash, 2009). Because these scores are available only through 2002-before our sample period begins — we use the 2002 values for all years of our analysis.

Because country-level wealth and differences in wealth between supplier and buyer countries could influence improvement rates, we control for GDP per capita (prior audit) as well as GDP per capita in buyer country (prior audit), obtained from World Bank data.

Summary statistics and correlations are reported in Tables 3 and 4.

[Insert Tables 3 and 4 here]

\footnotetext{
${ }^{10}$ We only include the lagged value for these country-level variables because they are very stable over the period of time between two consecutive supplier audits. In particular, the correlation between FDI inflows at prior and focal audits is 0.90 and the correlation between GDP per capita at prior and focal audits is 0.99 .

${ }^{11}$ FDI inflows measures net inflows of FDI (that is, inflows less divestment during the previous year) used to acquire a lasting management interest (that is, $10 \%$ or more of a company's voting stock was purchased by international entities) in the supplier's country. It is composed of equity capital, earnings reinvestment, and other short-term and long-term capital as shown in the country's balance of payments.
} 


\section{ESTIMATION AND RESULTS}

We test our hypotheses by estimating a model that predicts improvement based on the independent and control variables described above and the following additional control variables. Whereas our hypothesized variables pertain to a supplier's prior audit, these same factors pertaining to the focal audit might influence the number of violations reported in that audit, which is used to construct our dependent variable. Since failing to account for these factors could bias our estimates, we also control for announced (focal audit) and maximum auditor training (focal audit). We do not include the focal-audit value of exposure risk because it is very stable over time — the correlation of exposure risk between prior and focal audits is 0.99 — and including it would substantially increase multicollinearity while adding little new information.

Because (a) several audit design elements and audit team characteristics at the prior audit could influence violations recorded in that audit and (b) these same factors at the focal audit could influence violations recorded in that audit, we include most audit-level controls_ — paid by supplier or third party, paid by unknown entity, re-audit, previous auditor, all-female audit team, mixed-gender audit team, and maximum auditor tenure - in the model twice to control for them at both the prior and focal audits.

We also include industry fixed effects and year fixed effects to control for potential differences in improvement rates between suppliers in different industries and between the years in our sample, respectively. Because suppliers might respond differently to buyers exerting varying levels of pressure based on the buyers' own institutional contexts (Toffel, Short, and Ouellet, 2015), we include fixed effects for buyer countries.

We log and then standardize press freedom (prior audit) and maximum auditor training (prior audit) to reduce skew, to facilitate an elasticity interpretation of coefficients in response to 
a one-standard-deviation change, and because we interact these variables with announced. We use the log form of all other continuous variables to facilitate their interpretations as elasticities.

\section{Identification}

Our identification strategy relies on the auditor assignment process being unrelated to our hypothesized variables. With these concerns in mind, we spoke at length with representatives of the social auditor that provided our data. They confirmed that team assignment is not based on any of our independent or control variables. Rather, auditors are assigned based on who is available on the audit date and who speaks the language of the supplier's managers and employees, while also ensuring that every team has at least one auditor who has been trained as a lead auditor.

\section{Empirical Results}

For context, we note that suppliers in our sample averaged 7.2 violations in their prior audit and 5.6 violations in their focal audit, an average improvement of 1.6 fewer violations. This 22 -percent improvement rate (calculated as $1.6 \div 7.2$ ) corresponds to the -0.22 sample average improvement rate reported in the summary statistics (Table 3).

We estimate our models using ordinary least squares (OLS) regression, clustering standard errors by the supplier's country, the most aggregated level of any of our explanatory variables.

[Insert Table 5 here]

We test our first three hypotheses with Model 1, our baseline model, and report results in Table 5 . The statistically significant negative coefficient on exposure risk $(\beta=-0.091 ; \mathrm{p}<0.01)$ reveals that suppliers tend to improve more in countries with greater press freedom and NGO density, which supports H1. The coefficient magnitude indicates that a one-standard-deviation 
increase in exposure risk (such as a change from Vietnam to the Philippines) is associated with an increase in improvement from an average of 22 percent to 32.8 percent, based on average predictions across our sample. ${ }^{12}$ This 32.8 percent decline from the baseline average of 7.2 violations constitutes a decline of 2.4 violations, which is one and a half times the average decline of 1.6 violations.

The statistically significant negative coefficient on announced (prior audit) in Model 1 $(\beta=-0.040 ; p<0.01)$ indicates that greater improvement follows announced audits than unannounced audits, which supports $\mathrm{H} 2 .{ }^{13}$ The coefficient magnitude indicates that suppliers whose prior audit was announced experienced an average 26-percent improvement, calculated by adding the average improvement $(-0.22)$ to the coefficient estimate $(-0.04)$. This corresponds to 0.3 fewer violations beyond the average decline (calculated by multiplying 4.1 percent by 7.23 , the average number of violations in the prior audit). The average predicted values indicate an average improvement rate of 23 percent after announced audits versus 19 percent after unannounced audits.

The statistically significant negative coefficient on the standardized maximum auditor training (prior audit) $(\beta=-0.029 ; \mathrm{p}<0.01)$ indicates that greater improvement tends to follow audits conducted by better-trained audit teams, which supports H3. The coefficient magnitude indicates that, on average, suppliers realize an additional 2.9-percentage point improvement when their prior audit was conducted by a team whose best-trained auditor had one-standarddeviation more training than the average team's best-trained auditor (that is, 12.7 training courses versus the average of 6.9). Such suppliers average a 25-percent decline (the sum of the -

\footnotetext{
${ }^{12} 32.8 \%$ is calculated by adding to 0.22 the product of 0.091 (the coefficient on exposure risk) and 1.19 (the standard deviation of exposure risk.

${ }^{13}$ Note that if announcing the prior audit gave factories time to hide or solve problems before auditors arrive, prior audits would yield fewer violations than they otherwise would, which would bias against our hypothesized result: the falsely depressed baseline violation count would make it more difficult to observe subsequent improvement.
} 
0.22 sample average and the -0.029 coefficient); a reduction of 1.8 violations from the prior to the focal audit, or 0.2 violations more than the average reduction of 1.6 violations.

To test Hypothesis 4, we add a term that interacts announced (prior audit) and maximum auditor training (prior audit) and report the results as Model 2 in Table 5. The statistically significant negative coefficient on the interaction term $(\beta=-0.040 ; p<0.01)$ indicates that bettertrained audit teams at prior audits tend to prompt more improvement when those prior audits were announced than when they were unannounced, which supports H4. We graph these results in Figure 1, which plots the average predicted effects of maximum auditor training (prior audit) on improvement, based on Model 2, for observations where prior audits were announced or unannounced. The downward-sloped dashed line indicates that for announced audits, bettertrained auditors at the prior audit prompt even more improvement. The relatively flat solid line indicates that for unannounced audits, suppliers' improvement rates are fairly constant regardless of how well-trained the prior audit team was.

Hypothesis 5 posits that auditor training will have a greater influence on improvement when audits are conducted in a cooperative manner, as indicated by an announced audit, than when audits trigger concerns of exposure and sanctions. Model 3 tests this by adding to the prior model an interaction term between exposure risk and maximum auditor training (prior audit). We compare the nonsignificant slightly positive coefficient on this interaction term $(\beta=0.001 ; \mathrm{p}$ $=0.83)$ to the statistically significant negative coefficient on the interaction between announced (prior audit) and the standardized maximum auditor training (prior audit) $(\beta=-0.040 ; \mathrm{p}<0.01)$ using a Wald test, which indicates that these two coefficients significantly differ (Wald $\mathrm{F}=$ $13.42 ; \mathrm{p}<0.01)$. 


\section{Robustness Tests}

To assess whether our results were sensitive to using maximum or averages team values for training and experience, we estimated the three models using team averages. The results are nearly identical to our primary results.

We also estimated the models by substituting standardized press freedom (prior audit) and standardized NGO density (prior audit) for risk exposure (prior audit), the principle component based on those two variables. Akin to our primary results, this model's statistically significant negative coefficients on press freedom $(\beta=-0.075 ; \mathrm{p}<0.01)$ and NGO density (prior audit) $(\beta=-0.041 ; \mathrm{p}<0.05)$ indicate that suppliers operating in institutional environments with greater press freedom and greater NGO pressure tend to improve more than suppliers in countries with less press freedom and less NGO pressure. This indicates that support for H1 is robust to the choice of measuring the construct as the principle component of press freedom and NGO pressure or as the underlying variables. To test whether our results supporting H5 are similarly robust, we reestimate Model 3 but interact auditor training with either press freedom or NGO density instead of risk exposure. The first of these two models yielded a significant negative coefficient on the interaction between announced (prior audit) and maximum auditor training (prior audit) $(\beta=-0.038 ; \mathrm{p}<0.01)$ and a nonsignificant coefficient on the interaction between press freedom (prior audit) and maximum auditor training (prior audit) $(\beta=0.009 ; \mathrm{p}=$ 0.22); a Wald test indicated that these coefficients differ significantly (Wald $F=14.36 ; \mathrm{p}<$ 0.01). Similarly, the second model yielded a statistically significant negative coefficient on the interaction between announced (prior audit) and the standardized maximum auditor training (prior audit) $(\beta=-0.042 ; \mathrm{p}<0.01)$ and a nonsignificant coefficient on the interaction between NGO density (prior audit) and maximum auditor training (prior audit) $(\beta=-0.003 ; \mathrm{p}=0.75)$; a 
Wald test indicates that these coefficients differ significantly (Wald $F=9.54 ; \mathrm{p}<0.01$ ). These results further support $\mathrm{H} 5$ by indicating that our primary result is robust to alternative measures.

Our primary results are also robust to several sample restrictions. Some third-party social audit protocols detail specific procedures, such as whether audits should be announced or unannounced. To determine whether our results were driven by third-party protocol audits, we reestimate our models on a subsample excluding the 152 observations where the prior or focal audit was conducted according to a third-party protocol such as Business Social Compliance Initiative (BSCI), Customs-Trade Partnership Against Terrorism (C-TPAT), Social Accountability (SA) 8000, Sedex Members Ethical Trade Audit (SMETA), and Waste Reduction Audit Protocol (WRAP). The results were nearly identical to our main results.

The amount of improvement might depend on the amount of time between the prior and focal audits, especially if it were a particularly short or long time. To assess whether those more extreme cases influenced our results, we estimated our models on a subsample that excluded the 1,719 audits that were conducted fewer than 48 days or more than 433 days after the prior audit (the 10th and 90th percentiles of time span, respectively). The results were nearly identical to our main results, although we observed a slight decline in the magnitude and significance of the coefficient on announced (prior audit) $(\beta=0.034 ; \mathrm{p}=0.08)$.

Overall, our primary results proved markedly stable throughout various robustness tests.

\section{DISCUSSION}

Taken together, our findings reveal that organizational structures adopted by TNCs for the instrumentally rational purpose of managing the pressure of private political activism are, indeed, associated with improvements in business practices under certain conditions. First, suppliers are more likely to improve when they face higher levels of external compliance 
pressure in their institutional environments. This finding is consistent with literature highlighting the importance of civil society actors in diffusing transnational norms (Keck and Sikkink, 1998) and it suggests that private political activism may be more effective when it is supported by broader civil society pressures.

Second, we find that suppliers improve more not only in the face of external institutional pressure, but also in response to cooperative gestures on the part of buyers. Specifically, suppliers improved more following audits for which they had advance notice. This finding is consistent with economic models predicting that compliance can develop iteratively in response to trusting or cooperative gestures on the part of those implementing the rules (e.g., Axelrod, 1984; Scholz, 1984; Ayres and Braithwaite, 1992) and is consistent with qualitative studies finding better compliance with labor codes of conduct by suppliers in trusting and cooperative relationships with buyers (Frenkel and Scott, 2002; Locke and Romis, 2007). At the same time, this finding highlights stark trade-offs that must be carefully considered in designing monitoring regimes. Prior research has demonstrated what many fear (O'Rourke, 2002; Esbenshade, 2004; Clean Clothes Campaign, 2005; Power, Ng, and Singh, 2008; AFL-CIO, 2013; Karunakaran, 2013; LeBaron and Lister, 2015); namely that supply chain auditors find fewer violations in audits that are pre-announced (Short, Toffel, and Hugill, 2016). Research on government regulatory regimes has shown that some regulated entities create "Potemkin villages" to hide obvious violations in advance of known inspections (Gray, 2006). Thus, a monitoring program that aims to collect the most complete and accurate information about supply chain conditions or that seeks to catch a supplier in the act of committing serious infractions might require different design choices from a program that seeks to foster improvement in working conditions over time. 
Finally, we find that suppliers are more likely to improve when their auditors are highly trained, but only in the context of cooperative monitoring arrangements in which audits are announced in advance. By contrast, highly trained auditors add no significant value where suppliers face external compliance pressures. To our knowledge, our study is the first to test how factors associated with supplier improvement interact with each other. We demonstrate that such factors are not discrete and additive, but rather are interdependent and can moderate one another. Our findings suggest the crucial importance of understanding these interactions and the need to design monitoring regimes with the institutional context in mind.

\section{Private Politics and Organizational Self-regulation}

In addition to theorizing and identifying conditions under which self-regulatory structures adopted in response to private political activism will be associated with changes in behavior, our study makes several important contributions to the literature. First, we begin a productive dialogue between the literatures on private politics and organizational self-regulation. Research on private politics, grounded in economic sociology and political economy, has tended to focus on the mobilization of collective action targeting private organizations and on organizational responses to that activism, including the adoption of self-regulatory structures (Baron, 2003; Eesley and Lenox, 2006; Baron and Diermeier, 2007; King and Soule, 2007; King, 2008; Soule, 2009; McDonnell and King, 2013; Bartley and Child, 2014; Mena and Waeger, 2014; McDonnell, King, and Soule, 2015), but it has paid little attention to whether and how those structures have changed the practices of organizations or the market conditions that originally motivated the activism. By contrast, studies of organizational self-regulation, grounded in economic deterrence theory and the socio-legal literature on compliance, have investigated conditions under which organizations adhere to the self-regulatory commitments they purport to 
adopt (Potoski and Prakash, 2005; Kalev, Dobbin, and Kelly, 2006; Short and Toffel, 2010; Lim and Tsutsui, 2012; Marquis and Qian, 2014), but this literature has had little interest in where those structures come from and whether their genealogy has any bearing on their efficacy. As activism for social change increasingly "goes private" and generates new forms of organizational self-regulation to govern markets, it is crucial to understand each stage of the private political process, from mobilization to organizational response to changes (or not) in practice.

The private politics literature, given its empirical focus on mobilization and response, tends to view the outcomes of private political activism as largely symbolic. For instance, studies find organizations using "impression management tactics" as a defense against activism (McDonnell and King, 2013: 411), making "concessions" or public commitments to conform to activists' demands (Eesley and Lenox, 2006; King, 2008), and adopting organizational structures such as CSR officers or board committees (McDonnell, King, and Soule, 2015). Drawing on the broader social movements literature, private politics research makes a persuasive case for the importance of symbolic outcomes; for instance, raising the public's political consciousness and constructing understandings among market actors "about what is valuable and appropriate" (King and Pearce, 2010; McDonnell and King, 2013: 410). However, this literature has neither theorized nor tested when the outcomes of private political activism might be "more than merely symbolic" (Short and Toffel, 2010) or what the implications of this might be. By demonstrating that codes and monitoring can meaningfully change the practices of organizations, our study answers calls to extend the literature on private politics into the realm of practical outcomes (Short and Toffel, 2010; De Bakker et al., 2013).

\section{Beyond the "Business Case” for Corporate Social Responsibility}


Our study similarly extends existing research on CSR — the constellation of “organizational practices that are intended to serve stakeholders beyond the firm's owners, including employees, customers, communities, and society at large" (Chin, Hambrick, and Treviño, 2013: 202). A substantial body of research has sought to understand what drives companies to adopt CSR practices, but has not focused on the outcomes of CSR adoption (Aguilera et al., 2007; David, Bloom, and Hillman, 2007; Marquis, Glynn, and Davis, 2007; Chiu and Sharfman, 2011; Chin, Hambrick, and Treviño, 2013; Briscoe, Gupta, and Anner, 2015). Another extensive literature focuses on the "business case" for CSR by investigating whether it is associated with various measures of corporate financial performance, including firm value (Margolis and Walsh, 2003; Orlitzky, Schmidt, and Rynes, 2003), cost of capital (El Ghoul et al., 2011), and credit ratings (Jiraporn et al., 2014). Our study moves beyond these financial metrics to investigate whether the adoption of socially responsible practices like codes and monitoring is associated with improvements in the social outcomes that they purport to address - in this case, working conditions. In doing so, our work answers calls for more research into CSR's substantive impacts (Margolis and Walsh, 2003; Marquis and Qian, 2014; Briscoe, Gupta, and Anner, 2015).

Our finding that codes and monitoring are, under certain conditions, associated with improvements in supplier labor standards challenges the framing of normative debates about CSR. These debates have been highly polarized, with some espousing the view that CSR can address a variety of social harms and enhance societal well-being (e.g., Margolis and Walsh, 2003) while others dismiss it as a smokescreen to mask the insidious activities of TNCs (e.g., Banerjee, 2007). Our study calls for a more nuanced, contextual, and empirically grounded assessment of the virtues and vices of CSR. 


\section{Self-regulation and the Shadow of the State}

Our study contributes to the literature on organizational self-regulation by demonstrating that self-regulatory structures can improve compliance even where the shadow of state regulation is faint. We identify factors associated with supplier compliance improvements in contexts known to lack robust enforcement of government labor regulation. Indeed, our empirical results find no evidence that the stringency of state regulatory regimes (as measured by labor laws scores) explains why some suppliers improve more than others. This places our study in some tension with existing research, which has consistently found that the efficacy of organizational self-regulatory structures depends on the background threat of state monitoring or intervention (King and Lenox, 2000; Short and Toffel, 2010; Lim and Tsutsui, 2012; Short, 2013; Marquis and Qian, 2014; Toffel, Short, and Ouellet, 2015). However, our findings support those who have argued that civil society actors can provide an alternative source of compliance pressure to government regulation (e.g., Ayres and Braithwaite, 1992; Mattli and Woods, 2009).

The varying findings in this literature might result from varying empirical contexts, some of which measure compliance with the standards of voluntary programs embedded in state-based regulatory regimes, while others measure adherence to privately imposed rules. While we do not identify a direct role for government in promoting compliance improvements with private codes of conduct, our finding that institutional pressures from press freedom and NGO activity are associated with greater improvement suggests an important background role for the state in maintaining a space for civil society actors to operate. Further theoretical development and empirical investigation is necessary to identify the importance of the state's regulatory presence relative to that of other factors associated with the success of self-regulation. 


\section{Compliance Knowledge Transfer in Monitoring Arrangements}

Finally, our study highlights the relationship between knowledge transfer and regulatory compliance improvement and suggests fruitful avenues for research and theory bridging these domains. While the importance of compliance assistance and information exchange are often posited in research on supply chain standards (e.g., Locke, Amengual, and Mangla, 2009) and in the broader literature on regulatory governance (e.g., Sabel and Zeitlin, 2012; de Burca, Keohane, and Sabel, 2014), to our knowledge, the role of information transfer in compliance improvement has not been empirically tested. Our finding that supplier compliance improves more following audits conducted by highly trained auditors and that this training effect is amplified under cooperative conditions strongly suggest that information transfer is a crucial mechanism for improving compliance. However, future research is needed to document more directly the types of information exchanged between auditors and suppliers, the channels and methods of knowledge transfer, and their relationship to compliance improvements.

Such research will require more dialogue between the literatures on standards compliance and knowledge transfer. The knowledge transfer literature has largely ignored the importance of information sharing in promoting regulatory compliance or compliance with social and environmental standards in supply chains. An extensive body of research on knowledge transfer examines the conditions under which information, expertise, and best practices can be transmitted between individuals, teams, and firms and within teams and firms (Hansen, 1999; Edmondson, Bohmer, and Pisano, 2001; Oxley and Wada, 2009), including supply chain partners (MacDuffie and Helper, 1997; Dyer and Chu, 2003; Kotabe, Martin, and Domoto, 2003; Modi and Mabert, 2007), but it provides little insight into how social auditors can best transfer compliance knowledge to audited firms. Indeed, this literature suggests many barriers impeding 
the transmission of information in this setting, including the geographic and cultural distance between buyers and suppliers (Szulanski, 1996; Almeida, Song, and Grant, 2002; Bhagat et al., 2002; Hernandez, 2014), the fact that the auditors who supply compliance information often have loose and fleeting social ties with the suppliers who receive it (Kotabe, Martin, and Domoto, 2003; Reagans and McEvily, 2003; Gomes-Casseres, Hagedoorn, and Jaffe, 2006), and the fact that the connection between code compliance and financial performance may not be immediately apparent to suppliers (who often fear it will erode their competitive advantage). Our study's suggestion that knowledge transfer can occur even under such conditions presents new opportunities for theorizing and empirical research in this field.

\section{Limitations and Future Research}

Our study has limitations but also suggests promising areas for future research. First, because all the suppliers in our sample were audited, our findings only address why some audited suppliers improve more rapidly than others. We do not address whether auditing is associated with more rapid improvement than other possible interventions such as more stringent government regulation, legally binding international standards, or labor union activities. These are vital questions for future research.

Second, our findings are subject to several data limitations. Our study examines factories that faced at least two social audits by a single firm. By omitting establishments that were audited just once, we exclude audits that buyers might have initiated as a first step toward establishing a supplier relationship that was subsequently abandoned. Our focus on a single auditing firm has the advantage of providing comparable auditor training data, but does not enable us to compare practices across auditing firms. Omitting certain types of code violations from our analysis enhanced the reliability of our improvement measure, but creates a need for 
future research to determine whether the factors we found to predict improvement would also do so with the types of violations we omitted, particularly those concerning freedom of association and collective bargaining. Data limitations also prevented us from controlling for some of the factors that prior studies have found to be predictive of regulatory compliance, such firm size and regulatory enforcement practices. While we believe that our proxies for key independent variables are reasonable, we cannot rule out the possibility that they are imperfect.

\section{Conclusion}

As private political strategies become increasingly important in pursuing social change, it is crucial to understand the full range of outcomes they can produce and the conditions under which these outcomes are likely. We identify key conditions under which self-regulatory structures adopted in response to private political activism measurably improve working conditions. Our findings suggest the need to look beyond the symbolism of organizational responses to assess how private political activism can improve corporate practices.

\section{REFERENCES}

AFL-CIO. 2013. Responsibility Outsourced: Social Audits, Workplace Certification and Twenty Years of Failure to Protect. http://www.aflcio.org/Learn-About-Unions/Global-LaborMovement/Responsibility-Outsourced-Report (accessed December 18, 2014).

Aguilera, R. V., D. E. Rupp, C. A. Williams, and J. Ganapathi. 2007. "Putting the S Back in Corporate Social Responsibility: A Multilevel Theory of Social Change in Organizations." Academy of Management Review 32(3): 836-863.

Almeida, P., J. Song, and M. Grant. 2002. "Are Firms Superior to Alliances and Markets? An Empirical Test of Cross-Border Knowledge Building.” Organization Science 13(2): 147161.

Amengual, M. 2010. "Complementary Labor Regulation: The Uncoordinated Combination of State and Private Regulators in the Dominican Republic.” World Development 38(3): 405414.

Ang, D., D. Brown, R. Dehejia, and R. Robertson. 2012. "Public Disclosure, Reputation Sensitivity, and Labor Law Compliance: Evidence from Better Factories Cambodia." Review of Development Economics 16(4): 594-607. 
Anner, M. 2012. "Corporate Social Responsibility and Freedom of Association Rights: The Precarious Quest for Legitimacy and Control in Global Supply Chains." Politics \& Society 40(4): 609-644.

Axelrod, R. 1984. The Evolution of Cooperation. New York: Basic.

Ayres, I., and J. Braithwaite. 1992. Responsive Regulation: Transcending the Deregulation Debate. New York: Oxford.

Banerjee, S. B. 2007. Corporate Social Responsibility: The Good, the Bad, and the Ugly. Northampton, MA: Edward Elgar.

Bardach, E., and R. A. Kagan. 1982/2002. Going by the Book: The Problem of Regulatory Unreasonableness. New Brunswick, NJ: Transaction.

Barkemeyer, R. 2009. "Beyond Compliance-Below Expectations? CSR in the Context of International Development.” Business Ethics: A European Review 18(3): 273-289.

Baron, D. P. 2003. “Private Politics.” Journal of Economics \& Management Strategy 12(1): 3166.

Baron, D. P., and D. Diermeier. 2007. "Strategic Activism and Nonmarket Strategy." Journal of Economic Management Strategy 16(3): 599-634.

Barrientos, S., and S. Smith. 2007. "Do Workers Benefit from Ethical Trade? Assessing Codes of Labour Practice in Global Production Systems." Third World Quarterly 28(4): 713-729.

Bartley, T. 2007. "How Foundations Shape Social Movements: The Construction of an Organizational Field and the Rise of Forest Certification." Social Problems 54(3): 229-255.

Bartley, T., and C. Child. 2014. "Shaming the Corporation: The Social Production of Targets and the Anti-Sweatshop Movement." American Sociological Review 79(4): 653-679.

Bartley, T., and N. Egels-Zandén. 2015. "Responsibility and Neglect in Global Production Networks: The Uneven Significance of Codes of Conduct in Indonesian Factories." Global Networks 15(S1): S21-S44.

Berliner, D., A. Regan Greenleaf, M. Lake, M. Levi, and J. Noveck. 2015. “Governing Global Supply Chains: What We Know (and Don't) About Improving Labor Rights and Working Conditions.” Annual Review of Law and Social Science 11: 193-209.

Bhagat, R. S., B. L. Kedia, P. D. Harveston, and H. C. Triandis. 2002. "Cultural Variations in the Cross-Border Transfer of Organizational Knowledge: An Integrative Framework." Academy of Management Review 27(2): 204-221.

Borgatti, S. P., and R. Cross. 2003. "A Relational View of Information Seeking and Learning in Social Networks.” Management Science 49(4): 432-445.

Briscoe, F., A. Gupta, and M. S. Anner. 2015. "Social Activism and Practice Diffusion: How Activist Tactics Affect Non-targeted Organizations." Administrative Science Quarterly 60(2): 300-332.

Campbell, J. 2007. "Why Would Corporations Behave in Socially Responsible Ways? An Institutional Theory of Corporate Social Responsibility.” Academy of Management Review 32(3): 946-967. 
Cheng, J.-H., C.-H. Yeh, and C.-W. Tu. 2008. "Trust and Knowledge Sharing in Green Supply Chains.” Supply Chain Management: An International Journal 13(4): 283-295.

Chin, M. K., D. C. Hambrick, and L. K. Treviño. 2013. "Political Ideologies of CEOs: The Influence of Executives' Values on Corporate Social Responsibility." Administrative Science Quarterly 58(2): 197-232.

Chiu, S., and M. Sharfman. 2011. "Legitimacy, Visibility, and the Antecedents of Corporate Social Performance: An Investigation of the Instrumental Perspective." Journal of Management 37(6): 1558-1585.

Clean Clothes Campaign. 2005. "Looking for a Quick Fix: How Weak Social Auditing Is Keeping Workers in Sweatshops." https://www.evb.ch/fileadmin/files/documents/Konsum/Quickfix05.pdf (accessed May 31, 2016).

Coleman, J. S. 1988. "Social Capital in the Creation of Human Capital." American Journal of Sociology 94(Supplement): S95-S120.

David, P., M. Bloom, and A. J. Hillman. 2007. "Investor Activism, Managerial Responsiveness, and Corporate Social Performance." Strategic Management Journal 28(1): 91-100.

De Bakker, F. G. A., F. den Hond, B. King, and K. Weber. 2013. "Social Movements, Civil Society and Corporations: Taking Stock and Looking Ahead." Organization Studies 34(5-6): 573-593.

de Burca, G., R. O. Keohane, and C. F. Sabel. 2014. "Global Experimentalist Governance." British Journal of Political Science 44(3): 477-486.

Deci, E. L., and R. M. Ryan. 1985. Intrinsic Motivation and Self-Determination in Human Behavior. New York: Plenum.

Dobbin, F., and J. Sutton. 1998. "The Strength of a Weak State: The Employment Rights Revolution and the Rise of Human Resources Management Divisions." American Journal of Sociology 104(2): 441-476.

Duflo, E., M. Greenstone, R. Pande, and N. Ryan. 2013. "Truth-telling by Third-party Auditors and the Response of Polluting Firms: Experimental Evidence from India." Quarterly Journal of Economics 128(4): 1499-1545.

Dyer, J. H., and W. Chu. 2003. "The Role of Trustworthiness in Reducing Transaction Costs and Improving Performance-Empirical Evidence from the United States, Japan, and Korea." Organization Science 14(1): 57-68.

Edelman, L. B. 1992. "Legal Ambiguity and Symbolic Structures: Organizational Mediation of Civil Rights Law.” American Journal of Sociology 97(6): 1531-1576.

Edmondson, A. C., R. M. Bohmer, and G. P. Pisano. 2001. "Disrupted Routines: Team Learning and New Technology Implementation in Hospitals." Administrative Science Quarterly 46(4): 685-716.

Eesley, C., and M. J. Lenox. 2006. "Firm Responses to Secondary Stakeholder Action." Strategic Management Journal 27(8): 765-781. 
Egels-Zandén, N. 2007. "Suppliers' Compliance with MNCs' Codes of Conduct: Behind the Scenes at Chinese Toy Suppliers.” Journal of Business Ethics 75(1): 45-62.

Elevate. 2016. http://www.elevatelimited.com/ (accessed March 15, 2016).

El Ghoul, S., O. Guidhami, C. Kwok, and D. Mishra. 2011. “Does Corporate Social Responsibility Affect the Cost of Capital?" Journal of Banking and Finance 35(9): 23882406.

Esbenshade, J. 2004. Monitoring Sweatshops: Workers, Consumers, and the Global Apparel Industry. Philadelphia: Temple University Press.

Etzion, D., and F. Ferraro. 2010. "The Role of Analogy in the Institutionalization of Sustainability Reporting.” Organization Science 21(5): 1092-1107.

Fransen, L. 2012. Corporate Social Responsibility and Global Labor Standards: Firms and Activists in the Making of Private Regulation. New York: Routledge.

Frenkel, S. J., and D. Scott. 2002. "Compliance, Collaboration, and Codes of Labor Practice: The adidas Connection." California Management Review 45(1): 29-49.

Frynas, J. G. 2005. "The False Developmental Promise of Corporate Social Responsibility: Evidence from Multinational Oil Companies." International Affairs 81(3): 581-598.

Gomes-Casseres, B., J. Hagedoorn, and A. B. Jaffe. 2006. "Do Alliances Promote Knowledge Flows?" Journal of Financial Economics 80(1): 5-33.

Gould, D. 2005. “The Problem with Supplier Audits.” Corporate Responsibility Management 2(1): 24-29.

Gray, G. C. 2006. "The Regulation of Corporate Violations: Punishment, Compliance, and the Blurring of Responsibility.” British Journal of Criminology 46(5): 875-892.

Greene, W. H. 2007. Econometric Analysis, 6th Edition. Upper Saddle River, NJ: Prentice Hall.

Greenhill, B., L. Mosley, and A. Prakash. 2009. "Trade-based Diffusion of Labor Rights: A Panel Study, 1986-2002.” American Political Science Review 103(4): 169-190.

Hansen, M. T. 1999. “The Search-Transfer Problem: The Role of Weak Ties in Sharing Knowledge across Organization Subunits.” Administrative Science Quarterly 44(1): 82-111.

Hernandez, E. 2014. "Finding a Home Away from Home: Effect of Immigrants on Firms' Foreign Location Choice and Performance.” Administrative Science Quarterly 59(1): 73 108.

Inkpen, A. C., and E. W. K. Tsang. 2005. "Social Capital, Networks, and Knowledge Transfer." Academy of Management Review 30(1): 146-165.

Intertek. 2016. "Global Supplier Management System.” http://www.intertek.com/consumer/auditing/global-supplier-management/ (accessed May 31, 2016).

Jiang, J. (X.), M. H. Stanford, and Y. Xie. 2012. “Does It Matter Who Pays for Bond Ratings? Historical Evidence.” Journal of Finance Economics 105(3): 607-621. 
Jiraporn, P., N. Jiraporn, A. Boeprasert, and K. Chang. 2014. "Does Corporate Social Responsibility (CSR) Improve Credit Ratings? Evidence from Geographic Identification.” Financial Management 43(3): 505-531.

Justice, D. W. 2006. “Corporate Social Responsibility and Society's Expectations of Business." Perspectives on Work 9(2): 14-16.

Kalev, A., F. Dobbin, and E. Kelly. 2006. "Best Practices or Best Guesses? Assessing the Efficacy of Corporate Affirmative Action and Diversity Policies." American Sociological Review 71(4): 589-617.

Karunakaran, N. 2013. "Retailers Like Marks \& Spencer, Walmart Readies to Address HumanRights Issues of Workers.” Economic Times (December 11). http://articles.economictimes.indiatimes.com/2013-12-10/news/45035505_1_marks-spencersupply-chains-factories (accessed May 4, 2016).

Keck, M. E., and K. Sikkink. 1998. Activists Beyond Borders. Ithaca, NY: Cornell University Press.

King, A. A., and M. J. Lenox. 2000. "Industry Self-Regulation without Sanctions: The Chemical Industry's Responsible Care Program.” Academy of Management Journal 43(4): 698-716.

King, B. G. 2008. "A Political Mediation Model of Corporate Response to Social Movement Activism.” Administrative Science Quarterly 53(3): 395-421.

King, B. G. 2014. "Reputational Dynamics of Private Regulation.” Socio-Economic Review 12(1): 200-206.

King, B. G., and N. A. Pearce. 2010. "The Contentiousness of Markets: Politics, Social Movements, and Institutional Change in Markets." Annual Review of Sociology 36: 249-267.

King, B. G., and S. A. Soule. 2007. "Social Movements as Extra-Institutional Entrepreneurs: The Effect of Protest on Stock Price Returns." Administrative Science Quarterly 52(3): 413-442.

Kotabe, M., X. Martin, and H. Domoto. 2003. “Gaining from Vertical Partnerships: Knowledge Transfer, Relationship Duration, and Supplier Performance Improvement in the U.S. and Japanese Automotive Industries.” Strategic Management Journal 24(4): 293-316.

LeBaron, G., and J. Lister. 2015. "Benchmarking Global Supply Chains: The Power of the 'Ethical Audit' Regime.” Review of International Studies 41(Special issue 5): 905-924.

Levine, D. I., M. W. Toffel, and M. S. Johnson. 2012. "Randomized Government Safety Inspections Reduce Worker Injuries with No Detectable Job Loss.” Science 336(6083): 907911.

Lim, A., and K. Tsutsui. 2012. "Globalization and Commitment in Corporate Social Responsibility: Cross-national Analyses of Institutional and Political-economy Effects." American Sociological Review 77(1): 69-98.

Locke, R. M. 2013. The Promise and Limits of Private Power: Promoting Labor Standards in a Global Economy. Cambridge, UK: Cambridge University Press.

Locke, R., M. Amengual, and A. Mangla. 2009. "Virtue Out of Necessity? Compliance, Commitment, and the Improvement of Labor Conditions in Global Supply Chains." Politics \& Society 37(3): 319-351. 
Locke, R. M., F. Qin, and A. Brause. 2007. "Does Monitoring Improve Labor Standards? Lessons from Nike.” Industrial and Labor Relations Review 61(1): 3-31.

Locke, R. M., B. A. Rissing, and T. Pal. 2013. "Complements or Substitutes? Private Codes, State Regulation and the Improvement of Labor Standards in Global Supply Chains." British Journal of Industrial Relations 51(3): 519-552.

Locke, R. M., and M. Romis. 2007. "Improving Work Conditions in a Global Supply Chain." MIT Sloan Management Review 48(2): 54-62.

Loewenstein, J., L. Thompson, and D. Gentner. 2003. "Analogical Learning in Negotiation Teams: Comparing Cases Promotes Learning and Transfer." Academy of Management Learning and Education 2(2): 119-127.

Luo, J., S. Meier, and F. Oberholzer-Gee. 2012. "No News Is Good News: CSR Strategy and Newspaper Coverage of Negative Firm Events." Harvard Business School Working Paper 12-091.

MacDuffie, J. P., and S. Helper. 1997. "Creating Lean Suppliers: Diffusing Lean Production through the Supply Chain." California Management Review 39(4): 118-151.

Margolis, J. D., and J. P. Walsh. 2003. "Misery Loves Companies: Rethinking Social Initiatives by Business." Administrative Science Quarterly 48(2): 268-305.

Marks, K. 2012. "Factory Workers Are 'Forced to Lie' During Adidas Safety Inspections." Independent (UK) (April 13). http://www.independent.co.uk/news/world/asia/factoryworkers-are-forced-to-lie-during-adidas-safety-inspections-7644018.html (accessed May 4, 2016).

Marquis, C., M. A. Glynn, and G. F. Davis. 2007 "Community Isomorphism and Corporate Social Action." Academy of Management Review 32(3): 925-945.

Marquis, C., and C. Qian. 2014. "Corporate Social Responsibility Reporting in China: Symbol or Substance?” Organization Science (25)1: 127-148.

Mattli, W., and N. Woods. 2009. "In Whose Benefit? Explaining Regulatory Change in Global Politics.” In W. Mattli and N. Woods (eds.), The Politics of Global Regulation: 1-43. Princeton, NJ: Princeton University Press.

Mayer, R. C., J. H. Davis, and F. D. Schoorman. 1995. "An Integrative Model of Organizational Trust." Academy of Management Review 20(3): 709-734.

McBarnet, D. 2007. "Corporate Social Responsibility beyond Law, through Law, for Law: The New Corporate Accountability.” In D. McBarnet, A. Voiculescu, and T. Campbell (eds.), The New Corporate Accountability: Corporate Social Responsibility and the Law: 9-56. Cambridge, UK: Cambridge University Press.

McDonnell, M.-H., and B. G. King. 2013. "Keeping Up Appearances: Reputation Threat and Prosocial Responses to Social Movement Boycotts." Administrative Science Quarterly 58(3): $387-419$.

McDonnell, M.-H., B. G. King, and S. A. Soule. 2015. "A Dynamic Process Model of Private Politics: Activist Targeting and Corporate Receptivity to Social Challenges." American Sociological Review 80(3): 654-678. 
McEvily, B., V. Perrone, and A. Zaheer. 2003. "Trust as an Organizing Principle." Organization Science 14(1): 91-103.

Mena, S., and D. Waeger. 2014. "Activism for Corporate Responsibility: Conceptualizing Private Regulation Opportunity Structures." Journal of Management Studies 51(7): 10911117.

Meyer, J. W., J. Boli, G. M. Thomas, and F. O. Ramirez. 1997. "World Society and the NationState." American Journal of Sociology 103(1):144-181.

Meyer, J. W., and B. Rowan. 1997. "Institutionalized Organizations: Formal Structure as Myth and Ceremony." American Journal of Sociology 83(2): 340-363.

Modi, S. B., and V. A. Mabert. 2007. "Supplier Development: Improving Supplier Performance through Knowledge Transfer." Journal of Operations Management 25(1): 42-64.

Mosley, L. 2011. Replication Data for: Collective Labor Rights Dataset. http://hdl.handle.net/1902.1/15590 (accessed August 29, 2013).

Nadler, J., L. Thompson, and L. Van Boven. 2003. "Learning Negotiation Skills: Four Models of Knowledge Creation and Transfer." Management Science 49(4): 529-540.

Nadvi, K., P. Lund-Thomsen, H. Xue, and N. Khara. 2011. "Playing against China: Global Value Chains and Labour Standards in the International Sports Goods Industry." Global Networks 11(3): 334-354.

Nolan, J. 2014. "Redefining the Rules of the Game: The Corporate Responsibility to Respect Human Rights." Utrecht Journal of International and European Law 7. DOI: http://dx.doi.org/10.5334/ujiel.ca.

Obstfeld, D. 2005. "Social Networks, the Tertius Iungens Orientation, and Involvement in Innovation." Administrative Science Quarterly 50(1): 100-130.

Oka, C. 2010a. "Accounting for the Gaps in Labour Standard Compliance: The Role of Reputation-conscious Buyers in the Cambodian Garment Industry." European Journal of Development Research 22(1): 59-78.

Oka, C. 2010b. "Channels of Buyer Influence and Labor Standard Compliance: The Case of Cambodia's Garment Sector." In D. Lewin, B. E. Kaufman, and P. J. Gollan (eds.), Advances in Industrial and Labor Relations 17: 153-183. Bingley, UK: Emerald Group.

Orlitzky, M., F. L. Schmidt, and S. L. Rynes. 2003 "Corporate Social and Financial Performance: A Meta-analysis." Organization Studies 24(3): 403-441.

O'Rourke, D. 2002. "Monitoring the Monitors: A Critique of Corporate Third-party Labour Monitoring." In R. Jenkins, R. Pearson, and G. Seyfang (eds.), Corporate Responsibility and Labour Rights: Codes of Conduct in the Global Economy: 196-207. London, Earthscan.

Oxley, J., and T. Wada. 2009. "Alliance Structure and the Scope of Knowledge Transfer: Evidence from U.S.-Japan Agreements." Management Science 55(4): 635-649.

Parker, C. 2002. The Open Corporation: Effective Self-Regulation and Democracy. Cambridge, UK: Cambridge University Press. 
Plambeck, E. L., and T. A. Taylor. Forthcoming. "Supplier Evasion of a Buyer's Audit: Implications for Motivating Supplier Social and Environmental Responsibility." Manufacturing \& Service Operations Management.

Potoski, M., and A. Prakash. 2005. "Green Clubs and Voluntary Governance: ISO 14001 and Firms’ Regulatory Compliance.” American Journal of Political Science 49(2): 235-248.

Power, C., I.-C. Ng, and M. Singh. 2008. "The Burden of Good Intentions.” Time International 171(25): 45-48.

Reagans, R., and B. McEvily. 2003. "Network Structure and Knowledge Transfer: The Effects of Cohesion and Range.” Administrative Science Quarterly 48(2): 240-267.

Reinholt, M., T. Pederson, and N. J. Foss. 2011. “Why a Central Network Position Isn't Enough: The Role of Motivation and Ability for Knowledge Sharing in Employee Networks." Academy of Management Journal 54(6): 1277-1297.

Rodríguez-Garavito, C. 2005. "Global Governance and Labor Rights: Codes of Conduct and Anti-sweatshop Struggles in Global Apparel Factories in Mexico and Guatemala.” Politics and Society 33(2): 203-233.

Ruggie, J. 2008. Protect, Respect and Remedy: A Framework for Business and Human Rights. Report of the Special Representative of the Secretary-General on the Issue of Human Rights and Transnational Corporations and Other Business Enterprises. Geneva: United Nations, Human Rights Council. http://www.reports-and-materials.org/Ruggie-report-7-Apr-2008.pdf (accessed July 5, 2015).

Ruwanpura, K. N. 2012. "Ethical Codes: Reality and Rhetoric. A Study of Sri Lanka's Apparel Sector" University of Southampton working paper. http://eprints.soton.ac.uk/337113/ (accessed May 31, 2016).

Sabel, C. F., and J. Zeitlin. 2012. "Experimentalist Governance.” In D. Levi-Faur (ed.), The Oxford Handbook of Governance: 169-183. Oxford, UK: Oxford University Press.

Scholz, J. T. 1984. “Cooperation, Deterrence, and the Ecology of Regulatory Enforcement." Law \& Society Review 18(2): 179-224.

Seidman, G. 2007. Beyond the Boycott: Labor Rights, Human Rights, and Transnational Activism. New York: Russell Sage Foundation.

Selznick, P. 1992. The Moral Commonwealth: Social Theory and the Promise of Community. Berkeley, CA: University of California Press.

Shamir, R. 2011. "Socially Responsible Private Regulation: World-Culture or WorldCapitalism?" Law \& Society Review 45(2): 313-336.

Shea, A., M. Nakayama, and J. Heymann. 2010. "Improving Labour Standards in Clothing Factories: Lessons from Stakeholder Views and Monitoring Results in Cambodia." Global Social Policy 10(1): 85-110.

Short, J. L. 2013. "Self-Regulation in the Regulatory Void: 'Blue Moon' or 'Bad Moon'?" Annals of the American Academy of Political and Social Sciences 649(1): 22-34. 
Short, J. L., and M. W. Toffel. 2010. "Making Self-Regulation More Than Merely Symbolic: The Critical Role of the Legal Environment." Administrative Science Quarterly 55(3): 361396.

Short, J. L., and M. W. Toffel. 2015. "The Integrity of Private Third-party Compliance Monitoring." Harvard Kennedy School Regulatory Policy Program Working Paper No. RPP2015-20.

Short, J. L., M. W. Toffel, and A. R. Hugill. 2016. "Monitoring Global Supply Chains." Strategic Management Journal, forthcoming.

Soule, S. A. 2009. Contentious and Private Politics and Corporate Social Responsibility. Cambridge, UK: Cambridge University Press.

Suchman, Mark C. 1995. "Managing Legitimacy: Strategic and Institutional Approaches." Academy of Management Review 20(3): 571-610.

Szulanski, G. 1996. "Exploring Internal Stickiness: Impediments to the Transfer of Best Practice within the Firm." Strategic Management Journal 17(S2): 27-43.

Tenbrunsel, A. E., and D. M. Messick. 1999. "Sanctioning Systems, Decision Frames, and Cooperation." Administrative Science Quarterly 44(4): 684-707.

Thomas-Hunt, M. C., T. Y. Ogden, and M. A. Neale. 2003. "Who's Really Sharing? Effects of Social and Expert Status on Knowledge Exchange within Groups.” Management Science 49(4): 464-477.

Thompson, L., D. Gentner, and J. Loewenstein. 2000. "Avoiding Missed Opportunities in Managerial Life: Analogical Training More Powerful Than Individual Case Training." Organization Behavior and Human Decision Processes 82(1): 60-75.

Toffel, M. W., J. L. Short, and M. Ouellet. 2015. "Codes in Context: How States, Markets, and Civil Society Shape Adherence to Global Labor Standards." Regulation \& Governance 9(3): 205-223.

UL Responsible Sourcing. 2015. "Supply Chain Certification." http://services.ul.com/service/supply-chain-certification/ (accessed May 15, 2016).

Utting, P. 2005. "Corporate Responsibility and the Movement of Business." Development in Practice 15(3-4): 375-388.

Weil, D., and C. Mallo. 2007. "Regulating Labour Standards via Supply Chains: Combining Public/Private Interventions to Improve Workplace Compliance.” British Journal of Industrial Relations 45(4): 791-814. 
Figure 1. Average Predicted Improvement Values Based on Varying Amounts of Maximum Auditor Training at Prior Audit, for Prior Audits That Were Unannounced or Announced

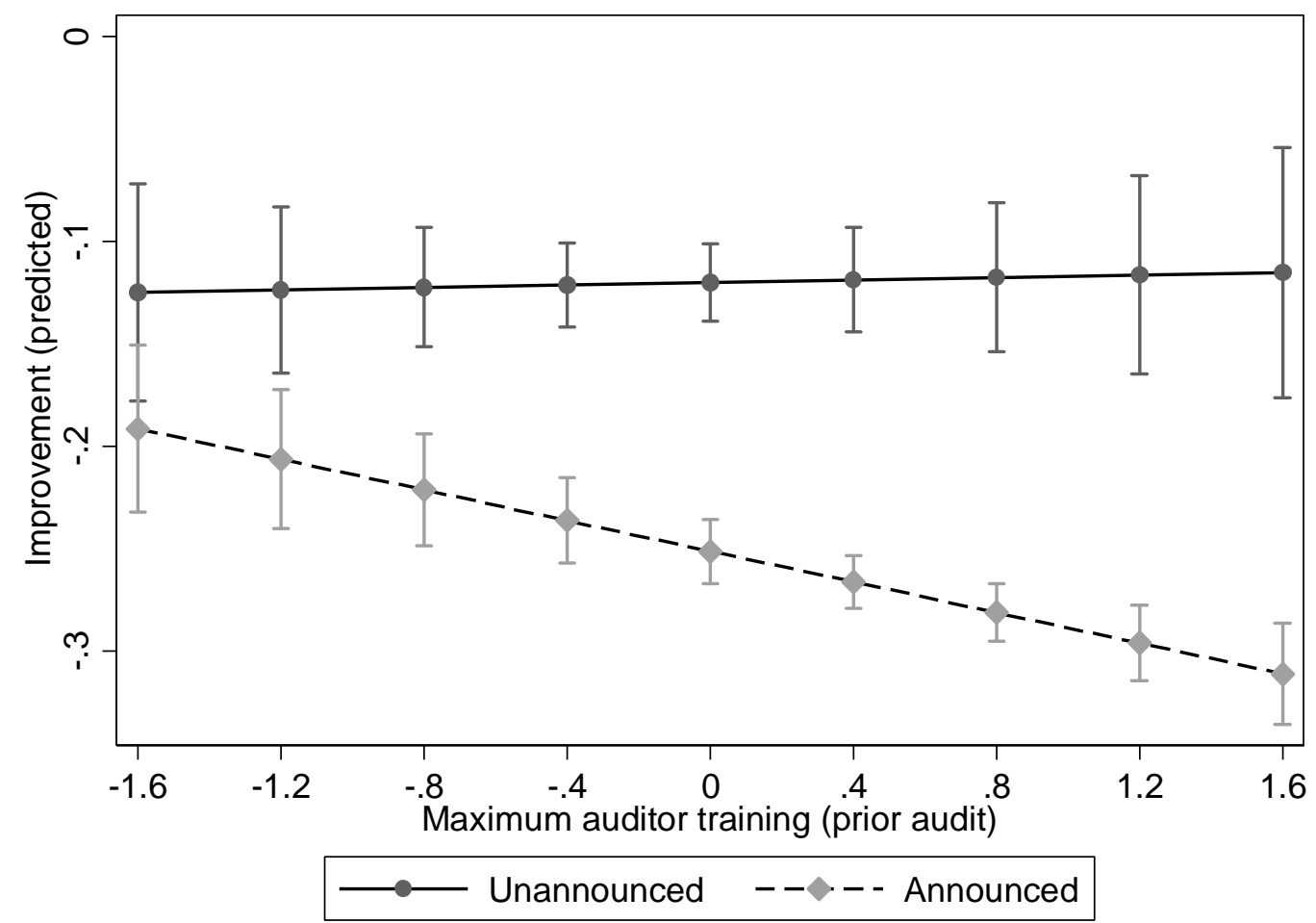

Note: This figure plots average predicted values of improvement from Model 2 when the prior audit was announced or unannounced, based on varying levels of maximum auditor training at the prior audit (logged and standardized) and all other variables at their actual values. 
Table 1. Industry Composition of Audits and Audited Suppliers

\begin{tabular}{lrrrr} 
& \multicolumn{2}{c}{ Audits } & \multicolumn{2}{c}{ Suppliers } \\
& Number & Percent & Number & Percent \\
\hline Accessories & 930 & $10.7 \%$ & 506 & $10.2 \%$ \\
Building materials & 143 & $1.6 \%$ & 74 & $1.5 \%$ \\
Chemicals and plastics & 47 & $0.5 \%$ & 36 & $0.7 \%$ \\
Electronics & 358 & $4.1 \%$ & 171 & $3.5 \%$ \\
Food, agriculture, beverages & 73 & $0.8 \%$ & 56 & $1.1 \%$ \\
Footwear & 191 & $2.2 \%$ & 103 & $2.1 \%$ \\
Furniture & 226 & $2.6 \%$ & 103 & $2.1 \%$ \\
Garment & 2,902 & $33.4 \%$ & 1,659 & $33.6 \%$ \\
Metal products & 85 & $1.0 \%$ & 45 & $0.9 \%$ \\
Paper, printing, and publishing & 117 & $1.3 \%$ & 71 & $1.4 \%$ \\
Services & 25 & $0.3 \%$ & 15 & $0.3 \%$ \\
Toys & 269 & $3.1 \%$ & 139 & $2.8 \%$ \\
Unknown (other and missing) & 3,311 & $38.2 \%$ & 1,962 & $39.7 \%$ \\
\hline Total & 8,677 & $100.0 \%$ & 4,940 & $100.0 \%$ \\
\hline
\end{tabular}

Table 2. Location of Audits and Audited Suppliers

\begin{tabular}{lrrrr} 
& \multicolumn{2}{c}{ Audits } & \multicolumn{2}{c}{ Suppliers } \\
Supplier country & Number & Percent & Number & Percent \\
\hline Bangladesh & 129 & $1.5 \%$ & 104 & $2.1 \%$ \\
Brazil & 40 & $0.5 \%$ & 32 & $0.6 \%$ \\
Canada & 33 & $0.4 \%$ & 19 & $0.4 \%$ \\
China (includes Hong Kong) & 6,345 & $73.1 \%$ & 3,416 & $69.1 \%$ \\
Egypt & 23 & $0.3 \%$ & 13 & $0.3 \%$ \\
Guatemala & 29 & $0.3 \%$ & 24 & $0.5 \%$ \\
India & 288 & $3.3 \%$ & 207 & $4.2 \%$ \\
Indonesia & 143 & $1.6 \%$ & 101 & $2.0 \%$ \\
Italy & 30 & $0.3 \%$ & 28 & $0.6 \%$ \\
Jordan & 36 & $0.4 \%$ & 22 & $0.4 \%$ \\
Korea, Republic of (South) & 53 & $0.6 \%$ & 39 & $0.8 \%$ \\
Malaysia & 40 & $0.5 \%$ & 25 & $0.5 \%$ \\
Mexico & 77 & $0.9 \%$ & 66 & $1.3 \%$ \\
Pakistan & 75 & $0.9 \%$ & 53 & $1.1 \%$ \\
Peru & 35 & $0.4 \%$ & 23 & $0.5 \%$ \\
Philippines & 121 & $1.4 \%$ & 71 & $1.4 \%$ \\
Sri Lanka & 55 & $0.6 \%$ & 40 & $0.8 \%$ \\
Thailand & 41 & $0.5 \%$ & 30 & $0.6 \%$ \\
Turkey & 84 & $1.0 \%$ & 59 & $1.2 \%$ \\
United States & 629 & $7.2 \%$ & 302 & $6.1 \%$ \\
Vietnam & 187 & $2.2 \%$ & 121 & $2.4 \%$ \\
Countries with $<20$ audits in sample & 184 & $2.1 \%$ & 145 & $2.9 \%$ \\
\hline Total & 8,677 & $100.0 \%$ & 4,940 & $100.0 \%$ \\
\hline
\end{tabular}


Table 3. Summary Statistics

\begin{tabular}{|c|c|c|c|c|}
\hline & Mean & SD & Min & Max \\
\hline Improvement & -0.22 & 0.86 & -3.26 & 3.26 \\
\hline Exposure risk (prior audit) & -0.34 & 1.19 & -1.14 & 4.02 \\
\hline Press freedom $\S$ (prior audit) & 0.00 & 1 & -0.77 & 2.37 \\
\hline NGO density§ (prior audit) & 0.00 & 1 & -0.55 & 4.85 \\
\hline Announced (prior audit) & 0.76 & 0.43 & 0 & 1 \\
\hline Maximum auditor training $\S$ (prior audit) & 0.00 & 1 & -1.65 & 1.64 \\
\hline Violations (prior audit) & 7.23 & 5.81 & 0 & 25 \\
\hline Violations $\dagger$ (prior audit) & 1.84 & 0.77 & 0 & 3.26 \\
\hline Announced (focal audit) & 0.77 & 0.42 & 0 & 1 \\
\hline Maximum auditor training $\dagger$ (focal audit) & 2.04 & 0.87 & 0 & 3.47 \\
\hline Paid by supplier or third party (prior audit) & 0.51 & 0.50 & 0 & 1 \\
\hline Paid by the buyer (prior audit) & 0.43 & 0.49 & 0 & 1 \\
\hline Paid by unknown entity (prior audit) & 0.06 & 0.24 & 0 & 1 \\
\hline Paid by supplier or third party (focal audit) & 0.52 & 0.50 & 0 & 1 \\
\hline Paid by the buyer (focal audit) & 0.42 & 0.49 & 0 & 1 \\
\hline Paid by unknown entity (focal audit) & 0.05 & 0.22 & 0 & 1 \\
\hline Prior audit was re-audit, but focal audit was not & 0.10 & 0.30 & 0 & 1 \\
\hline Focal audit was re-audit, but prior audit was not & 0.38 & 0.49 & 0 & 1 \\
\hline Prior and focal audit were re-audits & 0.19 & 0.40 & 0 & 1 \\
\hline Auditor exposure $\uparrow$ (prior audit) & 0.72 & 0.78 & 0 & 4.39 \\
\hline Previous auditor (prior audit) & 0.10 & 0.30 & 0 & 1 \\
\hline Previous auditor (focal audit) & 0.22 & 0.42 & 0 & 1 \\
\hline Audit sequence & 1.84 & 1.31 & 1 & 11 \\
\hline All-female audit team (prior audit) & 0.53 & 0.50 & 0 & 1 \\
\hline Mixed-gender audit team (prior audit) & 0.16 & 0.37 & 0 & 1 \\
\hline All-female audit team (focal audit) & 0.50 & 0.50 & 0 & 1 \\
\hline Mixed-gender audit team (focal audit) & 0.18 & 0.38 & 0 & 1 \\
\hline Maximum auditor tenure $\uparrow$ (prior audit) & 1.86 & 0.28 & 0.69 & 2.77 \\
\hline Maximum auditor tenure $\dagger$ (focal audit) & 1.78 & 0.32 & 0.69 & 2.77 \\
\hline FDI inflows $\dagger$ (prior audit) & 1.54 & 0.38 & -0.45 & 3.41 \\
\hline Labor laws $\uparrow(2002)$ & 3.12 & 0.12 & 2.30 & 3.35 \\
\hline GDP per capita $\uparrow$ (prior audit) & 7.78 & 1.00 & 5.61 & 10.68 \\
\hline GDP per capita in buyer country $\dagger$ (prior audit) & 10.59 & 0.26 & 6.59 & 10.85 \\
\hline
\end{tabular}

$\mathrm{N}=8,677$ audits. $\uparrow$ indicates logged. $\S$ indicates logged, then standardized. 


\section{Table 4. Correlations}
(1) Improvement
(2) Exposure risk (prior audit)
(3) Press freedom $\S$ (prior audit)
(4) NGO density $\S$ (prior audit)
(5) Announced (prior audit)
(6) Maximum auditor training§ (prior audit)
(7) Violations $\uparrow$ (prior audit)
(8) Paid by supplier or third party (prior audit)
(9) Paid by the buyer (prior audit)
(10) Paid by unknown entity (prior audit)
(11) Prior audit was re-audit, but focal audit was not
(12) Focal audit was re-audit, but prior audit was not
(13) Prior and focal audit were re-audits
(14) Auditor exposure $\uparrow$ (prior audit)
(15) Previous auditor (prior audit)
(16) Audit sequence
(17) All-female audit team (prior audit)
(18) Mixed-gender audit team (prior audit)
(19) Maximum auditor tenure $\uparrow$ (prior audit)
(20) FDI inflows $\dagger$ (prior audit)
(21) Labor laws $\dagger$ (2002)
(22) GDP per capita $\uparrow$ (prior audit)
(23) GDP per capita in buyer country $\dagger$ (prior audit)

\begin{tabular}{|c|c|c|c|c|c|c|c|c|c|c|c|c|c|c|c|c|c|c|c|c|}
\hline \multirow{2}{*}{$\begin{array}{l}(1) \\
1.00\end{array}$} & $(2)$ & (3) & (4) & (5) & (6) & (7) & (8) & (9) & (10) & (11) & (12) & (13) & (14) & (15) & (16) & (17) & (18) & (19) & (20) & (21) (22) \\
\hline & & & & & & & & & & & & & & & & & & & & \\
\hline 0.03 & 1.00 & & & & & & & & & & & & & & & & & & & \\
\hline 0.03 & 0.96 & 1.00 & & & & & & & & & & & & & & & & & & \\
\hline 0.02 & 0.95 & 0.84 & 1.00 & & & & & & & & & & & & & & & & & \\
\hline-0.07 & -0.13 & -0.15 & -0.10 & 1.00 & & & & & & & & & & & & & & & & \\
\hline-0.06 & -0.17 & -0.18 & -0.15 & 0.02 & 1.00 & & & & & & & & & & & & & & & \\
\hline-0.57 & -0.29 & -0.29 & -0.26 & 0.09 & 0.04 & 1.00 & & & & & & & & & & & & & & \\
\hline 0.00 & -0.28 & -0.29 & -0.23 & 0.16 & -0.03 & 0.05 & 1.00 & & & & & & & & & & & & & \\
\hline 0.02 & 0.26 & 0.27 & 0.22 & -0.18 & 0.03 & -0.07 & -0.88 & 1.00 & & & & & & & & & & & & \\
\hline-0.04 & 0.05 & 0.05 & 0.04 & 0.04 & 0.02 & 0.05 & -0.26 & -0.22 & 1.00 & & & & & & & & & & & \\
\hline 0.21 & -0.03 & -0.03 & -0.03 & -0.02 & -0.08 & -0.18 & 0.03 & -0.02 & -0.03 & 1.00 & & & & & & & & & & \\
\hline-0.27 & -0.08 & -0.08 & -0.07 & 0.07 & 0.05 & 0.31 & 0.05 & -0.07 & 0.04 & -0.26 & 1.00 & & & & & & & & & \\
\hline-0.02 & -0.15 & -0.16 & -0.13 & -0.02 & 0.04 & -0.02 & 0.12 & -0.09 & -0.06 & -0.17 & -0.38 & 1.00 & & & & & & & & \\
\hline-0.06 & 0.00 & 0.00 & 0.00 & -0.18 & 0.25 & 0.02 & -0.22 & 0.22 & 0.01 & -0.06 & 0.01 & -0.10 & 1.00 & & & & & & & \\
\hline 0.03 & 0.17 & 0.16 & 0.16 & -0.06 & 0.06 & -0.12 & -0.05 & 0.06 & -0.02 & 0.06 & -0.13 & 0.11 & 0.03 & 1.00 & & & & & & \\
\hline 0.08 & -0.08 & -0.08 & -0.08 & -0.02 & 0.29 & -0.17 & 0.04 & -0.01 & -0.07 & 0.16 & -0.24 & 0.26 & 0.00 & 0.20 & 1.00 & & & & & \\
\hline 0.00 & -0.13 & -0.12 & -0.13 & 0.03 & -0.02 & 0.02 & 0.03 & -0.03 & -0.01 & 0.02 & -0.01 & 0.02 & -0.05 & -0.08 & 0.01 & 1.00 & & & & \\
\hline-0.02 & -0.01 & -0.01 & -0.02 & 0.00 & 0.09 & 0.03 & 0.01 & -0.01 & 0.01 & -0.01 & 0.00 & 0.00 & 0.07 & 0.05 & 0.06 & -0.47 & 1.00 & & & \\
\hline 0.01 & 0.20 & 0.20 & 0.17 & -0.07 & -0.34 & -0.02 & 0.00 & -0.01 & 0.03 & 0.02 & -0.04 & -0.02 & -0.17 & 0.00 & -0.09 & 0.02 & 0.04 & 1.00 & & \\
\hline-0.03 & -0.44 & -0.55 & -0.28 & 0.11 & 0.27 & 0.16 & 0.18 & -0.17 & -0.01 & 0.01 & 0.05 & 0.08 & 0.05 & -0.08 & 0.11 & 0.05 & 0.02 & -0.19 & 1.00 & \\
\hline-0.02 & -0.43 & -0.41 & -0.41 & 0.03 & 0.10 & 0.09 & 0.09 & -0.09 & 0.00 & 0.00 & -0.01 & 0.05 & -0.03 & -0.14 & 0.08 & 0.20 & 0.00 & -0.03 & 0.25 & 1.00 \\
\hline 0.00 & 0.58 & 0.59 & 0.53 & -0.16 & 0.05 & -0.20 & -0.21 & 0.19 & 0.04 & -0.03 & -0.09 & -0.10 & -0.01 & 0.09 & 0.10 & 0.06 & -0.04 & 0.22 & -0.21 & $0.10 \quad 1.00$ \\
\hline-0.01 & 0.03 & 0.04 & 0.02 & 0.12 & 0.11 & -0.06 & 0.00 & 0.13 & -0.25 & -0.01 & 0.00 & 0.01 & -0.05 & 0.03 & 0.09 & 0.01 & 0.01 & -0.03 & -0.01 & $\begin{array}{ll}0.02 & 0.09\end{array}$ \\
\hline
\end{tabular}

$\mathrm{N}=8,677$ audits. $\dagger$ indicates logged. $\S$ indicates logged, then standardized. 


\section{Table 5. Regression Results}

Dependent variable: Improvement

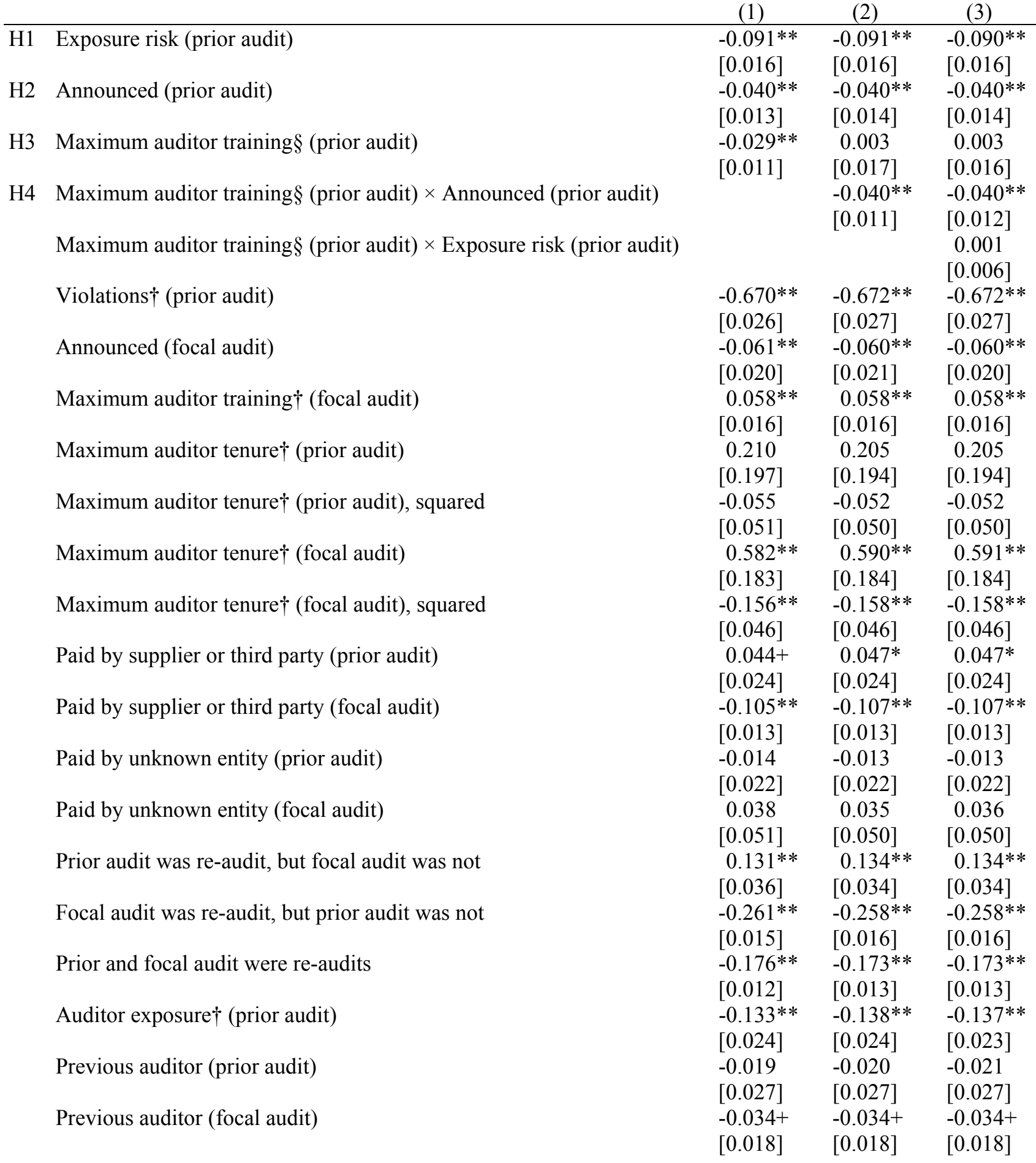

(continued on next page) 


\section{Table 5 (continued)}

All-female audit team (prior audit)

\begin{tabular}{ccc}
-0.009 & -0.009 & -0.009 \\
{$[0.013]$} & {$[0.013]$} & {$[0.014]$} \\
0.022 & 0.022 & 0.022 \\
{$[0.024]$} & {$[0.024]$} & {$[0.024]$} \\
$0.067^{* *}$ & $0.067^{* *}$ & $0.067^{* *}$ \\
{$[0.018]$} & {$[0.018]$} & {$[0.018]$} \\
$0.127^{* *}$ & $0.127^{* *}$ & $0.127^{* *}$ \\
{$[0.027]$} & {$[0.027]$} & {$[0.027]$} \\
$0.068+$ & $0.068+$ & $0.068+$ \\
{$[0.040]$} & {$[0.040]$} & {$[0.040]$} \\
-0.160 & -0.161 & -0.160 \\
{$[0.115]$} & {$[0.116]$} & {$[0.116]$} \\
$-0.049^{* *}$ & $-0.051^{* *}$ & $-0.051^{* *}$ \\
{$[0.016]$} & {$[0.016]$} & {$[0.016]$} \\
0.010 & 0.001 & 0.001 \\
{$[0.029]$} & {$[0.031]$} & {$[0.031]$} \\
Yes & Yes & Yes \\
Yes & Yes & Yes \\
Yes & Yes & Yes \\
Yes & Yes & Yes \\
\hline 8,677 & 8,677 & 8,677 \\
4,940 & 4,940 & 4,940 \\
0.41 & 0.41 & 0.41 \\
& & $13.42^{* *}$
\end{tabular}

H5 F value of Wald test: are the two interaction coefficients equivalent?

Ordinary least squares (OLS) regression coefficients with standard errors clustered by supplier country in brackets. ${ }^{* *} \mathrm{p}<0.01,{ }^{*} \mathrm{p}<0.05,+\mathrm{p}<0.10$. $\dagger$ indicates logged. $\S$ indicates logged, then standardized. Baseline (omitted) categories are paid by the brand for focal and prior audit and neither focal nor prior are re-audits. All models include dummy variables to indicate instances in which the following variables were missing data and thus recoded to 0: auditor exposure (prior audit) (4,339 audits), previous auditor (prior audit) (4,154 audits), and previous auditor (focal audit) (9 audits). 